\title{
OPTIMALISASI PEMBATASAN DANA KAMPANYE PEMILIHAN UMUM KEPALA DAERAH SEBAGAI PENCEGAHAN INVESTASI POLITIK YANG KORUPTIF* $^{*}$
}

\author{
Ibnu Sina Chandranegara ${ }^{* *}$ dan Nanda Sahputra Umara ${ }^{* * * *}$ \\ Departemen Hukum Tata Negara dan Departemen Hukum Pidana, \\ Fakultas Hukum, Universitas Muhammadiyah Jakarta, \\ Jl. KH. Ahmad Dahlan, Cirendeu, Jakarta Selatan, 15419
}

\begin{abstract}
Regulation concerning limiting on campaign funds have not proven to limit campaign funds from donors with binding interests. Therefore, the needs to identify various weaknesses in the regulation concerning a limitation on campaign funds to optimize clean campaign by preventing conflicts of interest, ensure transparency and ensure independence in making post election policies. Normative legal research methods used in this study starts from primary legal materials including all laws and regulations concerning campaign funds in regional head election and literature review which related to regional head election, secondary materials and tertiary material. This research concludes that it is necessary to affirm the limitation of campaign funds, regulating composition of contributors with the reasonableness ratio, reformulation of sanctions which excess the limit of campaign funds, and application of investigative audit.
\end{abstract}

Keywords: political finance, election, corruption.

\section{Intisari}

Saat ini regulasi pembatasan dana kampanye terkait pemasukan terbukti belum mampu membatasinya dari penyumbang dengan kepentingan yang mengikat. Oleh karena itu, identifikasi kelemahan dari regulasi pembatasan dana kampanye untuk mengoptimalisasi pembatasan dana kampanye diperlukan untuk mencegah konflik kepentingan, menjamin transparansi asal sumbangan dan menjamin kemandirian dalam mengambil kebijakan tanpa terikat dengan donatur kampanye. Metode penelitian yuridis normatif digunakan dengan meneliti bahan pustaka. Bahan hukum primer yaitu, peraturan perundang-undangan yang mengatur mengenai dana kampanye dalam pemilu, khususnya pemilu kepala daerah, Bahan hukum sekunder dan Bahan hukum tersier. Penelitian ini menghasilkan kesimpulan bahwa perlu penegasan pembatasan dana kampanye yang bersumber dari perorangan, penegasan komposisi penyumbang dengan rasio kewajaran, reformulasi sanksi kelebihan dana kampanye, dan penerapan audit investigasi.

Kata Kunci: dana kampanye, pemilu, korupsi.

\section{Pokok Muatan}

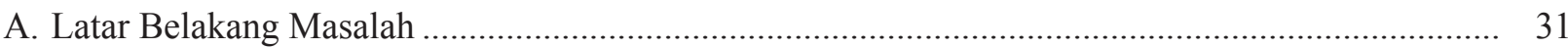

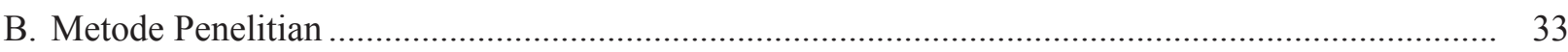

C. Hasil Penelitian dan Pembahasan .................................................................................................. 33

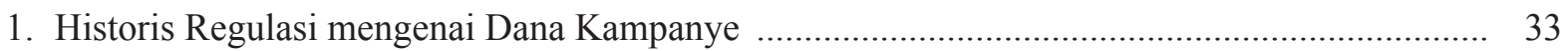

2. Kelemahan Regulasi Dana Kampanye dan Korupsi Kebijakan ............................................... 38

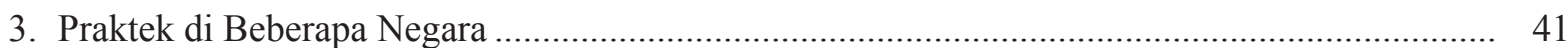

4. Optimalisasi Pembatasan Dana Kampanye ………............................................................... 45

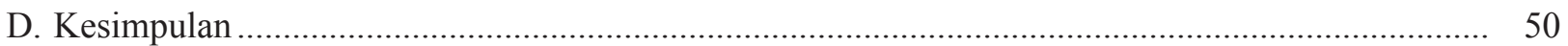

Hasil Penelitian Kolaborasi yang didanai oleh Pusat Pengkajian dan Pengembangan Ilmu Hukum (P3IH) UMJ pada Tahun 2019

Alamat korespondensi: ibnusinach@umj.ac.id

*** Alamat korespondensi: nandasahputra94@gmail.com 


\section{A. Latar Belakang Masalah}

Diantara banyak faktor penting agar sistem demokrasi berfungsi dengan baik, persoalan pembiayaan kampanye dalam pemilihan umum (Pemilu) sesungguhnya memiliki peranan penting. Bagi beberapa pendapat, menyadari bahwa uang mempunyai peranan penting dalam arena politik, uang bahkan berfungsi sebagai bentuk ekspresi kebebasan berbicara serta sebagai instrumen yang efektif untuk menginformasikan pemilih dan membangun demokrasi yang inklusif. Namun, bagi beberapa pendapat lain, penggunaan uang yang tidak terkendali dalam politik dapat mengikis fungsi demokrasi karena dapat menyebabkan kampanye berlebihan, akses yang tidak setara terhadap kekuasaan, dan politisi yang terikat dengan kelompok-kelompok kepentingan khusus. ${ }^{1}$ Dalam prakteknya, hampir setiap negara dengan pluralisme politik telah mengatur mengenai pembatasan dana dalam pemilihan umum mulai dari kewajiban menginformasikan sumber sumbangan, kewenangan pengungkapan dana sumbangan tersebut, hingga formula persyaratan untuk membatasi kontribusi kampanye dan/atau belanjanya.

Riset Marcin Walecki menguraikan bahwa dalam 60 negara demokrasi terdapat 25 negara telah memiliki regulasi mengenai batasan dana kampanye. Beberapa negara tersebut diantaranya Kanada, Perancis, Irlandia, Israel, Italia, Selandia Baru, Spanyol, dan negara-negara Britania Raya termasuk di dalamnnya Inggris. ${ }^{2}$ Negara-negara seperti Kanada dan Inggris bahkan telah membatasi belanja kampanye oleh partai dan individu selama beberapa dekade terakhir. ${ }^{3}$ Fakta terbaru bahkan menyatakan bahwa dua pertiga dari negara-negara Organisation for Economic Co-operation and Development (OECD) telah mempunyai regulasi mengenai batas pengeluaran kampanye untuk partai atau kandidat. ${ }^{4}$ Salah satu dari beberapa pengecualian di antara negara-negara maju adalah Amerika Serikat, dimana Mahkamah Agung Amerika Serikat dalam kasus McCutcheon $v$. Federal Election Commission memutuskan bahwa pembatasan dana kampanye adalah inkonstitusional dan berpotensi melanggar hak kebebasan berbicara. ${ }^{5}$

Pasca jatuhnya rezim Orde Baru, dana yang dihabiskan dalam kampanye pemilu nyatanya semakin meningkat; demikian juga dengan gelombang dana yang berputar dalam penyelenggaran maupun kontestasi pilkada. Peningkatan jumlah dana itu tidak hanya terjadi pada biaya penyelenggaraan yang dibebankan pada Anggaran Pendapatan dan Belanja Negara (APBN) dan Anggaran Pendapatan dan Belanja Daerah (APBD) tetapi juga biaya kampanye yang harus

1 Mengenai hal ini dapat membandingkan Stephen Coate, "Pareto-Improving Campaign Finance Policy", American Economic Review, Vol. 94, No. 3, 2004, hlm. 628-655, Andrea Prat, "Campaign Advertising and Voter Welfare", Review of Economic Studies, Vol. 69, No. 4, 2002, hlm. 999-1017 dan Susan E. Scarrow, "Political Finance in Comparative Perspective", Annual Review of Political Science, Vol. 10, No. 1, 2007, hlm. 193-210.

2 Marcin Walecki, 2007, Spending Limits As a Policy Option, IFES Political Finance White Paper Series, hlm. 3.

3 Saat ini, partai politik di Kanada hanya dapat membelanjakan 73,5 sen untuk setiap pemilih di distrik di mana mereka bersaing. Di Britania Raya, legislasi yang mengatur pengeluaran telah ada sejak Undang-undang Pencegahan Tindak Pidana Korupsi 1883. Pada pemilihan umum 2005, belanja kampanye di tingkat nasional dibatasi sekitar US \$ 42.000 per konstituen yang dipertandingkan. Susan E. Scarrow, Op. cit., hlm. 210.

4 Bruno Wilhem Speck, 2013, Money in politics: Sound Political Competition and Trust in Government, OECD Background paper, hlm. 16-17.

5 Mahkamah Agung Amerika Serikat pada medio 2014 dalam perkara McCutcheon v. Federal Election Commission telah membatalkan ketentuan mengenai pembatasan keseluruhan jumlah dana yang bisa diberikan para donor bagi kampanye politik. berdasarkan ketentuan pembatasan dana kampanye, para donor bisa memberi sumbangan kepada para calon dan kegiatan politik sebanyak yang diinginkan asalkan jumlah totalnya tidak melebihi 123,300\$. Putusan itu diambil dengan dengan perbandingan 5 berbanding 4 hakim yang menentang. Kelima hakim agung yang setuju berasal dari partai konservatif dan diangkat oleh presiden dari Partai Republik, sementara empat hakim lainnya berasal dari partai liberal diangkat oleh presiden dari Partai Demokrat. Ketua hakim agung, John Robert dalam putusan tersebut bahkan menolak pendapat pemerintahan Presiden Barack Obama bahwa pembatasan sumbangan diperlukan untuk memerangi korupsi dalam politik. John Robert mengemukakan Spending large sumsof money in connection with elections, but not in connection with an effort to control the exercise of an officeholder's official duties, does not give rise to such quid pro quo corruption. Nor does the possibility that an individual who spends large sums may garner "influence over or access to" elected officials or political parties. And because the Government's interest in preventing the appearance of corruption is equally confined to the appearance of quid pro quo corruption, the Government may not seek to limit the appearance of mere influence or access. Paul Waldman, 2014, How Our Campaign Finance System Compares to Other Countries, The American Prospect, hlm. 4 
ditanggung partai politik, calon anggota legislatif, calon presiden, dan calon kepala daerah. ${ }^{6}$ Selain itu, kenaikan harga pokok kebutuhan kampanye akibat inflasi tahunan dengan sendirinya menaikkan total harga kebutuhan kampanye. Demikian juga penambahan jumlah pemilih, jumlah kursi yang diperebutkan, dan jumlah calon, mengakibatkan total biaya kampanye menjadi berlipat. Selain faktor ekonomi dan demografi tersebut, peningkatan dana kampanye juga disebabkan oleh faktor politik. Perubahan sistem pemilu atau instrumen sistem pemilu nyatanya telah melipatgandakan biaya kampanye. Akhirnya, kampanye di media massa elektronik, khususnya televisi, yang semakin mahal, juga berdampak langsung pada penambahan biaya kampanye.

Salah satu faktor yang mendapat perhatian adalah tingginya peran korporasi swasta sebagai pemberi sumbangan dana kampanye, hal ini ditenggarai akibat kebutuhan biaya kampanye yang sangat besar, sehingga pelibatan korporasi swasta menjadi jalan keluar untuk mengumpulkan dana kampanye, keterlibatan korporasi swasta yang masif sebagai sponsor, tentu saja akan berdampak pada adanya persepsi investasi politik/jasa balas budi antara partai politik, calon peserta pemilu dengan sponsornya. Adanya hubungan timbal balik pasca pemilu merupakan konsekuensi yang sulit dihindari berdampak kepada munculnya potensi lahirnya tindak pidana korupsi pada tahapan sebelum ataupun sesudah pemilu. Misalnya korupsi dalam pemberian izin di berbagai bidang, seperti bidang usaha izin tambang, property, dan bidang usaha lainnya yang kemudian menabrak peraturan perundang-undangan misalnya aturan tata ruang. Konsekuensi dan korelasi yang demikian itu muncul, karena upaya balas jasa atau bahkan komitmen yang dibangun sebelum pemilu.
Akhirnya, bukannya kualitas personal dan aspirasi yang promosikan dikedepankan, melainkan rencana untuk pengembalian maupun komitmen kepentingan sponsor semasa peghimpunan dana kampanye. Gambaran sebagaimana terurai faktanya telah beberapa kali terjadi dalam praktinya, antara lain:

a. Pasca Pemilihan umum Kepala Derah (Pilkada) Kabupaten Kutai Kartanegara, Kalimantan Timur, pada 2010, pemerintah daerah mengeluarkan 191 Izin Usaha Pertambangan (IUP) baru, padahal setahun sebelumnya hanya 93 IUP. Begitu juga Kabupaten Beli, Nusa Tenggara Timur. Pada 2010 ada 54 IUP yang diterbitkan pemerintah daerah, padahal pada 2009 hanya 7 IUP. Hal ini juga terjadi di tempat lain seperti Musi Banyuasin (Sumatera Selatan), Bengkulu Tengah, Tebo (Jambi), dan Tanah Bambu (Kalimantan Selatan). ${ }^{7}$

b. Kasus penangkapan Bupati Buol Amran Batalipu yang memiliki skandal penyuapan dengan pengusaha sekaligus pengurus Partai Demokrat, Hartati Murdaya. Hartati memiliki kepentingan untuk mengurus hak guna usaha perkebunan dan memberikan suap kepada Bupati Amran senilai Rp 3 miliar, yang kebetulan saat itu menjadi kontestan pemilihan umum kepala daerah 2012. ${ }^{8}$ Hasil penelitian Wahana Lingkungan Hidup Indonesia (WALHI) Bengkulu tahun 2009-2010 juga menunjukkan bahwa saat Pemilu dan Pilkada digelar, pemerintah daerah kerap kali mengobral pemberian izin di bidang pertambangan. ${ }^{9}$

c. Gubernur Sulawesi Tenggara Periode 2008-2017 Nur Alam terbukti bersalah oleh majelis hakim karena menerima gratifikasi sebesar Rp 40 miliar atas pemberian IUP oleh PT Anugerah Harisma Barakah (AHB). Nur Alam

Team Kompas, "Biaya Pilkada Picu Korupsi”, http://www.ti.orid/index.php/news/2016/09/28/biaya-pilkada-picu-korupsi, diakses tanggal 20 Desember 2019.

Felix Natnaniel, "Bisnis Tambang Merebak Seiring Pilkada Serentak", https://tirto.id/bisnis-tambang-merebak-seiring-pilkada-serentak$c G 4 x$, diakses pada 20 Desember 2019.

Ade Irawan, et. al., 2012, Korupsi Pemilukada, Indonesian Corruption Watch, Jakarta, hlm. 18-19.

$9 \quad$ Tri Hayati, 2011, "Perizinan Pertambangan di Era Reformasi Pemerintahan Daerah: Studi tentang Perizinan Pertambangan Timah di Pulau Bangka”, Disertasi, Fakultas Hukum Universitas Indonesia, hlm. 12-13. 
juga dinilai terbukti menerima gratifikasi sebesar $\mathrm{Rp} \quad 40$ miliar dan melanggar Pasal 12B UndangUndang Nomor 31 tahun 1999 tentang Pemberantasan Tindak Pidana Korupsi (selanjutnya disebut UU 31/1999) sebagaimana telah diubah dengan UU Nomor 20 tahun 2001 tentang Perubahan atas UU 31/1999 jo Pasal 64 ayat (1) Kitab Undang-Undang Hukum Pidana (KUHP). ${ }^{10}$

d. Izin reklamasi di Daerah Khusus Ibukota (DKI) Jakarta yang menuai polemik permainan politik sampai perizinannya di ambil alih oleh pemerintah pusat, yang pada nyatanya banyak penelitian dan ahli yang berpendapat bahawa reklamasi tidak sesuai dengan ketentuan tata ruang dan Undang-Undang Lingkungan Hidup. Kemudian di periode Gubernur Anies Baswedan reklamasi ditutup.

Apabila merujuk kepada beberapa doktrin, setidaknya terdapat 3 (tiga) modus terkait pendanaan kampanye yang bernuasa investasi koruptif, yaitu: pertama, pola quid pro quo donations yaitu ketika partai atau kandidat menerima dana kampanye untuk melakukan sesuatu sesuai keinginan penyumbang. ${ }^{11}$ Modus ini sering juga dikenal dengan "dana kampanye mengikat". Kedua, pola candidate's or partie's misuse of state and public administrative resources for electoral purposes, yaitu penggunaan dana dan sumber daya pemerintah untuk kepentingan pemilu. Hal ini dikenal dengan abuses of power. ${ }^{12}$ Ketiga, bribery of voters and election officials, hal ini lebih dikenal dengan sebutan money politics atau politik uang. ${ }^{13}$ Berdasarkan hal-hal sebagaimana diatas, penelitian mendefinisikan investasi politik yang koruptif adalah sebagaimana dimaksud dalam modus pertama, yaitu dana sumbangan yang berpotensi membawa konsekuensi komitmen yang diemban oleh calon peserta pemilu. Berdasarkan hal tersebut ini penelitian ini dimaksudkan untuk mengidentifikasi apa sajakah kelemahan dalam regulasi kampanye saat ini sehingga masih terdapat celah sumbangan dana kampanye yang "mengikat", dan perubahan-perubahan apa yang harus diatur dalam aturan dana kampanye agar dapat mencegah investasi yang koruptif. Tujuan penelitian ini adalah untuk memperkuat regulasi dana kampanye yang mampu mencegah adanya dana kampanye mengikat guna mencegah kejahatan korupsi pasca pemilu khususnya pemilihan umum kepala daerah.

\section{B. Metode Penelitian}

Penelitian ini menggunakan metode penelitian yuridis normatif. Penelitian ini dilakukan dengan cara meneliti bahan pustaka, mulai dari bahan hukum primer yaitu, antara lain segala peraturan perundang-undangan yang mengatur mengenai dana kampanye dalam pemilu dan khususnya pemilu kepala daerah, bahan hukum sekunder (bahan hukum yang memberikan penjelasan terhadap bahan hukum primer) dan bahan hukum tersier (bahan hukum yang memberikan petunjuk maupun penjelasan terhadap bahan hukum primer dan sekunder).

\section{Hasil Penelitian dan Pembahasan \\ 1. Historis Regulasi mengenai Dana Kampa- nye \\ Sepanjang sejarah pelaksanaan pemilu di} Indonesia, pembatasan dana kampanye tidak selalu mendapatkan arah pengaturan yang jelas dan menutup celah perbuatan koruptif. Selama masa Orde Lama dan Orde Baru, pengaturan tentang dana kampanye Pemilu tidak diatur dalam peraturan

\footnotetext{
Putusan Pengadilan Tinggi DKI Jakarta Nomor 16/Pid.Sus-TPK/2018/PT.DKI perihal Banding perkara Nur Alam, 28 Maret 2018.

11 Fowler, Anthony, Haritz Garro, dan Jorg L. Spenkuch, 2017, "Quid Pro Quo? Corporate Returns to Campaign Contributions”, Makalah, hlm. 8 .

12 Rebecca L. Brown and Andrew D. Martin. "Rhetoric and Reality: Testing the Harm of Campaign Spending." New York University Law Review, Vol. 90, 2015, hlm. 1066.

13 Open Society Institute, 2005, "Monitoring Election Campaign Finance: a Handbook For NGOs". Open Society Institute, hlm. 12.
} 
perundang-undangan. ${ }^{14}$ Namun, pasca jatuhnya Orde Baru pengaturan mengenai dana kampanye diperkenalkan dengan lingkup yang lebih luas, yaitu pengaturan dana kampanye pemilihan legislatif, kepala daerah dan Presiden. Undang-Undang Nomor 3 tahun 1999 yang menjadi dasar penyelenggaraan Pemilu 1999 mencantumkan dua pasal yang mengatur sumber dana, larangan dana asing, dan laporan dana kampanye. ${ }^{15}$ Pengaturan ini masih sangat terbatas daripada yang diperlukan. Namun dibandingkan dengan Undang-Undang Nomor 15 Tahun 1969 tentang Pemilihan Umum Anggotaanggota Badan Permusyawaratan/Perwakilan Rakyat yang menjadi dasar penyelengaraan pemilupemilu Orde Baru, Undang-Undang Nomor 3 Tahun 1999 tentang Pemilihan Umum merupakan peletak dasar pengaturan dana kampanye berikutnya. Pasca Perubahan Undang-Undang Dasar Negara Republik Indonesia 1945 (UUD NRI 1945), pengaturan pembatasan dana kampanye terurai ke dalam beberapa bentuk ketentuan yaitu melalui UndangUndang Nomor 12 Tahun 2003 t entang Pemilihan Umum Anggota Dewan Perwakilan Rakyat, Dewan Perwakilan Daerah, dan Dewan Perwakilan Rakyat Daerah ${ }^{16}$, Undang-Undang Nomor 10 Tahun 2008 tentang Pemilihan Umum Anggota Dewan
Perwakilan Rakyat, Dewan Perwakilan Daerah, dan Dewan Perwakilan Rakyat Daerah, dan UndangUndang Nomor 8 Tahun 2012 tentang Pemilihan Umum Anggota Dewan Perwakilan Rakyat, Dewan Perwakilan Daerah, dan Dewan Perwakilan Rakyat Daerah untuk pemilu legislatif; Undang-Undang Nomor 23 Tahun 2003 tentang Pemilihan Umum Presiden dan Wakil Presiden ${ }^{17}$ dan Undang-Undang Nomor 42 Tahun 2008 tentang Pemilihan Umum Presiden dan Wakil Presiden untuk pemilu presiden, dan Undang-Undang Nomor 32 Tahun 2004 Pemerintahan Daerah untuk pilkada. ${ }^{18}$ Ketentuanketentuan tersebut pada pokoknya mengatur: (1) sumber dana kampanye yang berasal dari partai politik, calon, dan sumbangan tidak mengikat; (2) batasan sumbangan perseorangan dan perusahaan; (3) jenis sumbangan yang dilarang; (4) laporan daftar penyumbang; (5) audit dana kampanye; (6) mekanisme pelaporan dana kampanye, dan (7) sanksi atas pelanggaran ketentuan dana kampanye.

Akan tetapi, meskipun telah diatur mengenai pembatasan dana kampanye, namun ditenggarai masih beberapa kelemahan antara lain, pengaturan mengenai sumber dana masih jauh dari transparan, mekanisme pelaporan yang cenderung membingungkan, tidak diaturnya mengenai belanja

14 Pengaturan dana kampanye Pemilu sama sekali tidak dicantumkan dalam (a) Undang-Undang No 7 Tahun 1953 tentang Pemilihan Anggota Konstituante dan Anggota Dewan Perwakilan Rakyat, dan PP No 9 Tahun 1954, yang menjadi dasar pelaksanaan Pemilu tahun 1955. (b) Undang-Undang No 15/1969 tentang Pemilihan Umum Anggota Badan Permusyawaratan/ Perwakilan Rakyat, yang menjadi dasar pelaksanaan Pemilu tahun 1971. (c) Undang-Undang No 4 Tahun 1971 tentang Perubahan atas Undang-Undang No 5 Tahun 1969 yang menjadi dasar pelaksanaan Pemilu tahun 1977. (d) Undang-Undang No 2 Tahun 1980 tentang Perubahan atas Undang-Undang No 15 Tahun 1969 tentang Pemilihan Umum Anggota Badan Permusyawaratan/ Perwakilan Rakyat sebagaimana telah diubah oleh Undang-Undang No 4 Tahun 1971 yang menjadi dasar pelaksanaan Pemilu tahun 1982. (e) Undang-Undang No 1 Tahun 1985 tentang Perubahan atas Undang-Undang No 15 Tahun 1969 tentang Pemilihan Umum Anggota Badan Permusyawaratan/ Perwakilan Rakyat sebagaimana telah diubah oleh Undang-Undang No 4 Tahun 1971 dan Undang-Undang No 2 Tahun 1980 yang menjadi dasar pelaksanaan Pemilu tahun 1987. (f) PP No 37 Tahun 1990 yang menjadi dasar pelaksanaan Pemilu tahun 1992 dan (g) PP Nomor 74 Tahun 1996 yang menjadi dasar pelaksanaan Pemilu tahun 1997.

15 Pasal 48 Undang-Undang 3 Tahun 1999 tentang Undang-Undang Nomor 3 Tahun 1999 tentang Pemilihan Umum (Lembaran Negara Republik Indonesia Tahun 1999 Nomor 23, Tambahan Lembaran Negara Republik Indonesia Nomor 3810).

16 Undang-Undang No. 12 tahun 2003 yang menjadi dasar penyelenggaraan pemilu legislatif memuat pengaturan dana kampanye partai politik yang menjadi peserta pemilu DPR, DPRD provinsi dan DPRD kabupaten/kota, serta pengaturan dana kampanye calon anggota DPD yang bersatus juga sebagai peserta pemilu DPD. Undang-Undang No. 12 tahun 2003 yang menjadi dasar penyelenggaraan pemilu legislatif memuat pengaturan dana kampanye partai politik yang menjadi peserta pemilu DPR, DPRD provinsi dan DPRD kabupaten/kota, serta pengaturan dana kampanye calon anggota DPD yang bersatus juga sebagai peserta pemilu DPD. Sekilas materi pengaturan dana kampanye sudah mencukupi, namun jika dicermati, pengaturan dana kampanye dalam Undang-Undang No. 12 Tahun 2003 belum menerapkan secara konsisten prinsip transparansi dan akuntabilitas: sumber dana banyak lubang, mekanisme pelaporan membingungkan, belanja kampanye tidak diatur, dan ketiadaan sanksi tegas bagi pelanggar.

17 Undang-Undang No 23 Tahun 2003 merupakan undang-undang pertama mengatur pemilu presiden. Mengadopsi pengaturan dana kampanye pemilu legislatif, undang-undang ini memuat hampir semua materi pengaturan yang diperlukan. merupakan undang-undang pertama mengatur pemilu presiden. Mengadopsi pengaturan dana kampanye pemilu legislatif, undang-undang ini memuat hampir semua materi pengaturan yang diperlukan.

18 Pengaturan dana kampanye pilkada sebagaimana tertuang dalam Undang-Undang No. 32 Tahun 2004, sebetulnya hanya copy paste dari Undang-Undang No. 23 Tahun 2003, sehingga masalah, kelemahan dan kekuranganya pun juga sama. 
kampanye, dan ketiadaan sanksi tegas bagi pelanggar. Selain itu, salah satu kelemahan yang menonjol pengaturan dana kampanye pemilu legislatif adalah tidak adanya pembatasan dana dari partai politik dan calon anggota legislatif, demikian juga dalam pemilu presiden dan pilkada, tidak ada pembatasan dana dari calon presiden dan wakil presiden dan calon kepala daerah dan wakil kepala daerah, serta partai politik yang mengusung pasangan calon tersebut. Akibatnya, berapa pun dana yang masuk dari partai politik dan calon dianggap legal, meski dana itu bisa didapatkan partai politik dan calon dari pihak lain dengan cara tidak legal. Di sisi lain, pengaturan dana kampanye dalam pemilu legislatif, pemilu presiden dan pilkada juga tidak membatasi belanja kampanye, sehingga peserta pemilu dipacu untuk menggelar kampanye semasif dan seintensif mungkin demi meraih suara. Ketiadaan batasan dana dari partai politik dan calon di satu pihak, dan ketiadaan pembatasan belanja kampanye di lain pihak, membuat pengeluaran dana kempanye menjadi tidak terkendali. Partai politik dan calon harus menanggung beban dana kampanye tinggi sehingga ini membuka ruang korupsi pasca pemilu nanti. ${ }^{19}$

Terlepas beragam kontroversi yang muncul, pengaturan dana kampanye untuk pilkada diatur oleh pemerintah dan DPR dengan menetapkan (Peraturan Pemerintah Pengganti Undang-Undang Nomor 1 Tahun 2014 tentang Perubahan atas Undang-Undang Nomor 27 Tahun 2007 tentang Pengelolaan Wilayah menjadi Undang-Undang Nomor 1 Tahun 2015 tentang Penetapan Peraturan Pemerintah Pengganti Undang-Undang Nomor 1 Tahun 2014 Tentang Pemilihan Gubernur, Bupati, Dan Walikota Menjadi Undang-Undang(selanjutnya disebut UU 1/2015) pada 20 Januari 2015. Namun, dikarenakan masih mengandung banyak kelemahan dan kekurangan dalam mengatur penyelenggaraan pilkada, pemerintah, dan Dewan Perwakilan Rakyat (DPR) mengubah UU 1/2015 melalui Undang-
Undang Nomor 8 Tahun 2015 tentang Perubahan atas Undang-Undang Nomor 1 Tahun 2015 tentang Penetapan Peraturan Pemerintah Pengganti Undang-Undang Nomor 1 Tahun 2014 Tentang Pemilihan Gubernur, Bupati, dan Walikota Menjadi Undang-Undang, undang-undang ini berusaha menekan atau mengurangi dana kampanye pilkada sekecil mungkin. Hal ini terlihat dari dua ketentuan berikut ini. Pertama, seperti undang-undang sebelumnya, Undang-Undang Nomor 1 Tahun 2015 jo Undang-Undang Nomor 8 Tahun 2015 menyebut tujuh metode kampanye: (a) pertemuan terbatas; (b) pertemuan tatap muka dan dialog; (c) debat publik/ debat terbuka antarpasangan calon; (d) penyebaran bahan kampanye kepada umum; (e) pemasangan alat peraga; f) iklan media massa cetak dan media massa elektronik; dan atau (g) kegiatan lain yang tidak melanggar larangan kampanye dan ketentuan peraturan perundang-undangan. Namun Pasal 65 ayat (2) UU No 1 Tahun 2015 jo UU No 8 Tahun 2015, menegaskan bahwa metode kampanye huruf c), d), e), dan f) difasilitasi oleh Komisi Pemilihan Umum (KPU) yang didanai APBN. Jadi, kampanye dalam bentuk debat publik, penyebaran bahan kampanye kepada umum, pemasangan alat peraga, dan iklan media massa, kini dibiayai negara; sedangkan partai politik dan pasangan calon hanya membiayai kampanye pertemuan terbatas dan pertemuan tatap muka dan dialog. Kedua, berbeda dengan undang-undang pemilu sebelumnya, undang-undang pilkada tersebut mencantumkan pembatasan dana kampanye. Pembatasan tersebut terurai dalam Pasal 74 ayat (9) UU No. 1 Tahun 2015 jo UU No. 8 Tahun 2015 yang kemudian diturunkan diturunkan ke dalam Peraturan KPU No. 8 Tahun 2015.

Pengaturan dana kampanye selanjutnya mendapatkan pembaruan kembali setelah munculnya UU No. 10 Tahun 2016 Tentang Perubahan Kedua atas UU No. 1 Tahun 2015 Tentang Perppu No. 1 Tahun 2014. Dalam undang-undang tersebut

19 Didik Supriyanto dan Lia Wulandari, 2013, Basa-Basi Dana Kampanye Pengabaian Prinsip Transparansi dan Akuntabilitas Peserta Pemilu, Yayasan Perludem, Jakarta. hlm 8-9. 
ditentukan bahwa sumbangan dana kampanye dapat diperoleh dari partai politik, pasangan calon, perseorangan, dan badan hukum swasta. Dalam peraturan ini tidak hanya mengatur asal sumbangan, lebih dari itu juga diatur batasan besaran sumbangan, seperti sumbangan dari perorangan $\mathrm{Rp}$ 75 Juta dan dari badan hukum swasta Rp 750 juta. $^{20}$ Penyumbang pun harus mempunyai data identitas pribadi dan lembaga swasta yang jelas. Artinya, tidak sembarang perorangan atau lembaga yang bisa menyumbang. Selanjutnya, pengaturan dana kampanye pilkada tidak hanya membatasi besaran sumbangan, namun besaran dana kampanye pun dibatasi dengan mmenggunakan rumus yang mempertimbangkan standar biaya daerah setelah diadakan rapat kesepakatan dengan tim pasangan calon. Penetapan pembatasan pengeluaran dana kampanye dengan memperhitungkan metode kampanye, jumlah kegiatan kampanye, perkiraan jumlah peserta kampanye, standar biaya daerah, bahan kampanye yang diperlukan, cakupan wilayah dan kondisi geografis, logistik, dan manajemen kampanye/konsultan. ${ }^{21}$ Pembatasan ini sebagai bentuk efisiensi dan efektivitas penggunaan dana kampanye.

Kombinasi antara tiga bentuk kampanye yang dibiayai negara dengan pembatasan dana kampanye, dapat mengurangi secara signifikan jumlah dana kampanye yang selama ini harus ditanggung oleh partai politik dan pasangan calon. Meskipun demikian dua ketentuan tersebut masih sangat terbuka sehingga bisa menimbulkan masalah dalam pelaksanannya. Misalnya, kampanye dalam pertemuan terbatas dan pertemuan tatap muka dan dialog, memang bisa dilakukan secara bebas oleh pasangan calon dan tim kampanye, kapan saja di mana saja selama masa kampanye. Namun apakah itu berarti KPU tidak diberi wewenang untuk mengatur pelaksanaan pertemuan terbatas dan pertemuan tatap muka dan dialog. Lantas jika dikaitan dengan wewenang KPU untuk membatasi dana kampanye, bukankah hal itu juga berlaku terhadap pembatasan dana kampanye untuk kampanye dalam bentuk pertemuan terbatas dan pertemuan tatap muka dan dialog?. Terlepas itu semua, ketentuan tentang pembatasan dana kampanye sesungguhnya menimbulkan multitafsir, antara lain pertama, apakah pembatasan itu hanya berlaku pada pengeluaran/belanja saja, atau juga mencakup pembatasan terhadak pemasukan/ sumbangan?; kedua, apakah wewenang membatasi dana kampanye itu hanya boleh dilakukan oleh KPU Provinsi dan KPU Kabupaten/Kota, atau KPU bisa membuat peraturan teknis, sehingga KPU Provinsi dan KPU Kabupaten/Kota tinggal melaksanakannya? Ketentuan-ketentuan yang multitafsir inilah yang harus dihadapi oleh KPU dalam membuat peraturan teknis dana kampanye sebagaimana diamanatkan oleh Pasal 75 ayat (5) UU No. 1 Tahun 2015 jo UU No. 8 Tahun 2015, yang menyatakan, "Ketentuan lebih lanjut mengenai sumbangan dan pengeluaran dana Kampanye pasangan calon diatur dengan Peraturan KPU.” Tidak hanya menafsirkan ketentuan undang-undang, dalam membuat peraturan tentang sumbangan dan pengeluaran dana kampanye, KPU juga diharuska membuat ketentuan-ketentuan baru yang tidak dicantumkan secara tekstual dalam UU No. 1 Tahun 2015 jo UU No. 8 Tahun 2015, tetapi dibutuhkan untuk menegakkan prinsip- prinsip pengaturan dana kampanye seperti keadilan, kesetaraan, serta transparansi dan akuntabilitas.

Berdasarkan hal tersebut, KPU pada akhirnya menetapkan Peraturan KPU No. 5 Tahun 2017 tentang Dana Kampanye yang menggantikan Peraturan KPU No. 8 Tahun 2015 dan Peraturan

20 Pasal 74 ayat (5) Undang-Undang No 8 Tahun 2015 tentang Undang-Undang Nomor 8 Tahun 2015 tentang Perubahan Atas Undang-Undang Nomor 1 Tahun 2015 tentang Penetapan Peraturan Pemerintah Pengganti Undang-Undang Nomor 1 Tahun 2014 tentang Pemilihan Gubernur, Bupati, Dan Walikota Menjadi Undang-Undang (Lembaran Negara Republik Indonesia Tahun 2015 Nomor 57, Tambahan Lembaran Negara Republik Indonesia Nomor 5678)

21 Pasal 74 ayat (7) UU No 8 Tahun 2015 tentang Undang-Undang Nomor 8 Tahun 2015 tentang Perubahan Atas Undang-Undang Nomor 1 Tahun 2015 tentang Penetapan Peraturan Pemerintah Pengganti Undang-Undang Nomor 1 Tahun 2014 tentang Pemilihan Gubernur, Bupati, Dan Walikota Menjadi Undang-Undang (Lembaran Negara Republik Indonesia Tahun 2015 Nomor 57, Tambahan Lembaran Negara Republik Indonesia Nomor 5678) 
KPU No. 13 Tahun 2016 mengenai perubahannya. Dalam regulasi yang baru ini ini, pembatasan dana kampanye ditentukan berbasis setiap item kegiatan kampanye. KPU menentukan rincian item kegiatan kampanye yang dibiayai negara dan yang dibiayai setiap pasangan calon. Dalam konteks ini, KPU Provinsi/Kabupaten/kota tinggal menentukan berapa besaran biaya setiap kegiatan kampanye sesuai standar biaya daerah masing-masing. Standar-standar dimaksud ditentukan melalui serangkaian rumus-rumus yang dikalikan dengan standar biaya daerah atas kualifikasi tertentu. ${ }^{22}$ Selain itu, Pasal 39 ayat (1) Peraturan KPU No. 5 Tahun 2017 menentukan bentuk dan mekanisme perikatan audit dana kampanye dalam pemilihan adalah audit kepatuhan. Akuntan publik yang ditunjuk untuk keperluan audit pun diatur sangat jelas dalam Pasal 43 Peraturan KPU No. 5 Tahun 2017. Misalnya, tidak berafiliasi secara langsung dengan pasangan calon dan partai politik, dan bukan dari partai politik yang mengusulkan. Dalam pelaksanaan audit dana kampanye merupakan sebuah perikatan atestasi yang mengacu kepada Standar Profesional Akuntan Publik (SPAP) khususnya Standar Atestasi (SAT) 500 mengenai kepatuhan. Dalam melaksanakan auditnya, akuntan publik akan merancang dan menjalankan prosedur audit untuk memperoleh keyakinan memadai terhadap kepatuhan asersi pasangan calon dengan dibantu paslon dalam menyediakan semua catatan dan dokumen yang diperlukan. ${ }^{23}$ Dalam hal audit dana kampanye, maka tidak hanya menampilkan fakta tetapi juga dapat membuat opini tentang kepatuhan peserta pilkada. Kepatuhan sebagaimana dimaksud adalah kepatuhan terhadap undangundang, seperti kepatuhan terhadap penyerahan laporan dana kampanye apakah tepat waktu atau tidak, apakah sumbangan kampanye telah patuh terhadap batasan maksimum dari perseorangan dan juga badan usaha, serta terkait dengan penyumbang dana kampanye kepatuhan terhadap penerimaan sumbangan dari pihak-pihak yang dilarang ketentuan undang-undang, misalnya menerima dana dari pihak asing, atau dana dari sumber anggaran negara seperti Badan Usaha Milik Negara (BUMN) / Badan Usaha Milik Daerah (BUMD).

Selain itu, dalam Peraturan KPU pun ikut diatur mengenai sanksi bagi peserta pilkada yang melanggar. Partai Politik atau Gabungan Partai Politik dan Pasangan Calon Perseorangan dilarang menerima sumbangan melebihi ketentuan termasuk menggunakannya. Sanksi yang diberikan tidak tanggung-tanggung yaitu pembatalan sebagai calon bagi pasangan calon kepala daerah. Tentunya sanksi yang diberikan berupa pembatalan sebagai calon ketika melakukan pelanggaran dengan menggunakan dana kampanye melebihi batas ketentuan. Kepastian ini diatur dalam Pasal 51, ${ }^{24}$ Pasal 52,,,$^{25}$ Pasal 53, ${ }^{26}$ dan Pasal 54, ${ }^{27}$ Peraturan KPU No. 5 Tahun 2017. Formulasi tersebut di

22 Pasal 12 ayat (2) Peraturan Komisi Pemilihan Umum No 5 Tahun 2017 tentang Dana Kampanye Peserta Pemilihan Gubernur dan Wakil Gubernur, Bupati dan Wakil Bupati, dan/atau, Walikota dan Wakil Walikota. (Berita Negara Republik Indonesia Tahun 2017 Nomor 828)

23 Emmy Hafild, 2008, Laporan Studi Standar Akuntasi Keuangan Khusus Partai Politik, Transparency International (TI) Indonesia Transparency International (TI), Jakarta. hlm 32-33.

24 Pasal 51 Peraturan Komisi Pemilihan Umum No 5 Tahun 2017 tentang Dana Kampanye Peserta Pemilihan Gubernur dan Wakil Gubernur, Bupati dan Wakil Bupati, dan/atau, Walikota dan Wakil Walikota. (Berita Negara Republik Indonesia Tahun 2017 Nomor 828) : "Setiap orang yang dengan sengaja memberikan keterangan yang tidak benar dalam laporan Dana Kampanye sebagaimana dimaksud dalam Pasal 8 ayat (2), dikenai sanksi sebagaimana diatur dalam Undang-Undang tentang Pemilihan."

25 Pasal 52 Peraturan Komisi Pemilihan Umum No 5 Tahun 2017 tentang Dana Kampanye Peserta Pemilihan Gubernur dan Wakil Gubernur, Bupati dan Wakil Bupati, dan/atau, Walikota dan Wakil Walikota. (Berita Negara Republik Indonesia Tahun 2017 Nomor 828) : "Partai Politik atau Gabungan Partai Politik dan Pasangan Calon Perseorangan yang melanggar ketentuan sebagaimana dimaksud dalam Pasal 7 ayat (1), ayat (2) dan ayat (3), dan Pasal 9 ayat (1), dikenai sanksi berupa pembatalan sebagai Pasangan Calon sebagaimana diatur dalam Undang-Undang tentang Pemilihan."

26 Pasal 53 Peraturan Komisi Pemilihan Umum No 5 Tahun 2017 tentang Dana Kampanye Peserta Pemilihan Gubernur dan Wakil Gubernur, Bupati dan Wakil Bupati, dan/atau, Walikota dan Wakil Walikota. (Berita Negara Republik Indonesia Tahun 2017 Nomor 828): "Pasangan Calon yang melanggar ketentuan pembatasan pengeluaran Dana Kampanye sebagaimana dimaksud dalam Pasal 12 ayat (4), dikenai sanksi berupa pembatalan sebagai Pasangan Calon."

27 Pasal 54 Peraturan Komisi Pemilihan Umum No 5 Tahun 2017 tentang Dana Kampanye Peserta Pemilihan Gubernur dan Wakil Gubernur, Bupati dan Wakil Bupati, dan/atau, Walikota dan Wakil Walikota. (Berita Negara Republik Indonesia Tahun 2017 Nomor 828): "Pasangan Calon yang terlambat menyampaikan LPPDK kepada KPU Provinsi/KIP Aceh atau KPU/KIP Kabupaten/Kota sampai batas waktu yang ditentukan sebagaimana dimaksud dalam Pasal 34 ayat (1) dan ayat (2), dikenai sanksi berupa pembatalan sebagai Pasangan Calon." 
satu sisi memiliki sejumlah dampak positif yaitu Pertama, pelaksanaan pilkada akan berjalan lebih sehat. Sebab, persaingan tidak lagi mengedepankan banyaknya modal uang, tetapi seberapa besar pengaruh yang dimiliki dalam merayu pemilih. Sekalipun calon memiliki uang dalam jumlah besar, tetapi yang calon tidak dapat menggunakannya melebihi yang ditentukan sesuai dengan aturan perundangan. ${ }^{28}$ Kedua, siapa pun yang akan menjadi calon kepala daerah agar ia dikenal, maka yang bersangkutan dipaksa untuk bertanam investasi sosial dan politik jauh sebelum pilkada dilaksanakan. ${ }^{29}$ Ketiga, perkembangan regulasi menunjukan bahwa pembatasan dana kampanye akan mendorong setiap calon lebih kreatif untuk mendekati pemilih. Pada saat yang sama, masyarakat pemilih pun akan dididik untuk tidak lagi berpikir pragmatis dalam menentukan pilihan.

\section{Kelemahan Regulasi Dana Kampanye dan Korupsi Kebijakan}

Merujuk kepada temuan Burhanuddin Muhtadi, maka dana kampanye akan memiliki porsi yang besar secara informal disumbang adalah untuk pembiayaan politik uang. ${ }^{30}$ Kondisi ini yang kemudian mendorong calon membuka seluas mungkin sumber pembiayaan, termasuk sumber yang tidak dilaporkan (informal). Keadaan ini meneguhkan bahwa praktik di lapangan baik sumber maupun pengeluaran tidak segaris lurus dengan ketentuan hukum. Yusfitriadi dalam penelitiannya setidaknya memberi gambaran problem pendanaan calon dalam pilkada yang dari sisi audit belum bisa dijangkau. Hal ini mengisyaratkan ada penerimaan dan pengeluaran yang yang luput dari pantauan audit tersebut dan memberikan kesimpulan bahwa tidak semua penerimaan dan pengeluaran dana kampanye dilaporkan. ${ }^{31}$ Di sisi lain, Meitzner pernah mengemukakan menyebutkan adanya penerimaan pembiayaan kampanye dari para pengusaha yang tidak tercatat. Selanjutnya dari sisi pengeluaran ada juga yang tidak dilaporkan, politik uang adalah pengeluaran yang pastinya tidak tercatat oleh karena kategori pengeluaran yang dilarang. ${ }^{32}$ Kondisi ini menjelaskan perihal banyak calon yang tidak jujur mencantumkan penerimaan dan pengeluaran dari sumber pihak ketiga.

Kondisi fundamental yang terkesan sulit dihindari adalah kebutuhan dana yang besar khususnya untuk melakukan politik uang. sumber pembiayaan informal umumnya berasal dari pengusaha sebagaimana terurai dalam Fitriyah. ${ }^{33}$ Rangkaian studinya itu menemukan shadow state dan informal economy penyelenggaraan pemerintahan daerah tidak lepas dari adanya sokongan pembiayaan yang diterima calon dari pemodal pengusaha selama proses pilkada. ${ }^{34}$ Titik lemah regulasi sebagaimana dikemukakan di atas menjadi semakin rentan apabila ditambah dengan berbagai faktor yang tidak mendukung, seperti minimnya peran partai politik dalam kerja-kerja elektoral. Seorang calon yang telah ditetapkan oleh Komisi Pemilihan Umum Daerah (KPUD) sebagai peserta pemilu, maka tiga hari setelahnya diperbolehkan melakukan aktivitas kampanye untuk memobilisasi pemilih. Akan tetapi, pada umumnya kerja-kerja yang demikian ini dilakukan oleh tim sukses yang dibentuk secara informal oleh

28 Didik Supriyanto, Lia Wulandari, Armanda Pransiska, dan Catherine Natalia (Editor), 2015, Dana Kampanye Pilkada: Pengaturan Teknis tentang Sumbangan, Pengeluaran, Dan Pelaporan Berdasarkan Undang-Undang No 1/2015 Juncto UU No 8/2015, Yayasan Perludem, Jakarta. hlm 21-22

29 Khairul Fahmi, Pembatasan Dana Kampanye Pilkada, Media Indonesia, 10 Maret 2015.

30 Burhanuddin Muhtadi, 2018, "Buying Votes in Indonesia: Partisans, Personal Networks, and Winning Margins", Disertasi, Australia National University.

31 Yusfitriadi, 2018, “Audit Dana Kampanye Pilkada Serentak 2015 di Indonesia: Studi Kasus di 11 Kabupaten/Kota”, dalam Mada Sukmajati dan Aditya Perdana (eds), Pembiayaan Pemilu Di Indonesia, Bawaslu, Jakarta. Hlm. 206.

32 Marcus Mietzner, 2011, "Funding Pilkada :Illegal Campaign Financing in Indonesia’s Local Elections", dalam Edward Aspinall and Gerry van Klinken (eds), The State And Illegality In Indonesia, KITLV Press, Leiden.

33 Fitriyah, 2018, "Botoh dalam Pilkada: Studi Kasus Dua Daerah di Jawa Tengah", Disertasi, Program Doktor Ilmu Sosial-FISIP Universitas Diponegoro. hlm 322.

$34 \quad$ Ibid, hlm 323-324. 
calon dan bukan tim kampanye yang didaftarkan resmi di KPUD.

Tim kampanye adalah tim yang formal, keanggotaannya diisi oleh elit partai politik pengusung, yakni para fungsionaris partai politik pengusung dan anggota DPR di tingkat pusat dan daerah, fokus tim kampanye pada konsolidasi partai politik dan sebagai juru kampenye saat rapat umum maupun rapat terbatas. Sifat kerja tim kampanye adalah resmi atau terlapor, seperti kapan jadwal kampanyenya dan dimana lokasi penyelengaraannya, siapa saja juru kampanye, berapa jumlah pemilih yang diundang hadir, termasuk berapa biayanya. Sementara, kerja elektoral di lapangan yang bertemu langsung pemilih adalah kerja tim sukses yang sifatnya informal dan dari sisi biaya terkait aktivitasnya tidak semuanya terlaporkan. Keanggotaan tim sukses ini diisi orang-orang yang dianggap menjadi tokoh masyarakat yang merepresentasikan komunitasnya di semua tingkatan wilayah administratif, meliputi ulama, tokoh perempuan, tokoh pemuda, ketua asosiasi pedagang kaki lima dan profesi informal lainnya, termasuk tokoh kelompok preman juga dirangkul. Oleh karena itu, pembiayaan semacam ini kadang melampaui atau tidak terlapor dari dana kampanye yang dibutuhkan. Keadaan ini menjadikan posisi dan peran partai politik menjadi lemah dan tidak sekuat pasangan calon, hal yang demikian ini menimbulkan korelasi dari segi pembiayaan. Bertumpunya aktivitas elektoral pada pasangan calon akibatnya melekat sebagai beban pribadi calon yang bersangkutan, calon dengan demikian membentuk, mengendalikan sekaligus membiayai kerja tim suksesnya sebagai mesin politik. Pada akhirnya, kebutuhan dana yang besar dan tidak terlapor menjadi tinggi. Apabila pengusaha menyadari kebutuhan dan kondisi tersebut, hadirnya sumbangan dengan pola quid pro quo donations menjadi conditio sine quad non.

Apabila meninjau berbagai jumlah pengeluaran pembiayaan pilkada yang jadi tanggungan seorang calon dan jika dibandingkan, angkanya jauh melampaui nilai kekayaan calon sebagaimana tertuang dalam laporan kekayaan Laporan Harta Kekayaan Penyelenggara Negara (LHKPN) para calon memunculkan total angka yang fantastis. Besaran modal ekonomi yang dimiliki pasangan calon sebagaimana yang terlaporkan jauh lebih kecil dari total pembiayaan pilkada. Sebagai misal, Kajian Komisi Pemberantasan Korupsi (KPK) menunjukkan rata-rata jumlah harta para pasangan calon yang maju di Pilkada Pada 9 Desember 2015 lalu adalah $\mathrm{Rp}$ 13.410.575.802. ${ }^{35}$

Sementara hasil kajian Penelitian dan Pengembangan Kementrian Dalam Negeri (Litbang Kemendagri) menunjukkan bahwa untuk menjadi walikota/bupati dibutuhkan biaya mencapai Rp 20 milyar- Rp 30 milyar rupiah dan untuk menjadi gubernur berkisar Rp 20 milyar-Rp 100 miliar. ${ }^{36}$ Pada akhirnya di lapangan tidak mudah mendapatkan informasi valid tentang besaran biaya yang riil dikeluarkan calon, akan tetapi informasi dari banyak sumber perkiraan besaran biaya calon yang menang sebagaimana hasil kajian Litbang Kemendagri tersebut. Selisih kesenjangan jurang biaya tersebut mengakibatkan pasangan calon kemudian aktif mencari sumber-sumber pendanaan informal, karena tidak semua pembiayaan bisa ditutup oleh uang pribadi ataupun uang resmi lainnya. Pada saat yang bersamaan, ada aktor-aktor ekonomi yang berminat menjadi pemodal calon, yang ini jamak sudah dilakukan oleh pengusaha. ${ }^{37}$ Umumnya pemodal ini memiliki sebutan botoh bagi pemodal masyarakat Jawa dalam ajang pilkades, ${ }^{38}$ atau getho untuk wilayah Banyumas. Botoh atau

\footnotetext{
35 KPK, 2016, "Laporan Studi Potensi Benturan Kepentingan Dalam Penda- naan Pilkada Direktorat penelitian dan Pengembangan KPK". Diakses http://acch.kpk.go.id/documents/ 10180/15049/Laporan+Studi+Potensi+Benturan+Kepentingan+dalam +Pendanaan+ Pilkada. pdf/ 5992b55a-91ef-4976-bab6-44f54d28baa9. Diakses pada 20 Desember 2019

36 Team TransaparencyInternational, "Biaya Pilkada Picu Korupsi”, diakses http://www.ti.or.id/index.php/ news/2016/ 09/28/biaya-pilkadapicu-korupsi. Diakses pada 20 Desember 2019

37 Yuki Fukuoka, "Politics, Business and the State in Post-Soeharto Indonesia." Contemporary Southeast Asia, Vol. 34, No 1, 2012, hlm. 83.

38 Fitriyah, Op. Cit. hlm 322
} 
getho di wilayah Jawa sama dengan sebutan cukong di wilayah Jabodetabek merupakan pemodal yang memiliki peranan penting dalam mengatur pemenang untuk kepentingan judi semata.

Kondisi sebagaimana terurai merupakan bibit lahirnya ekosistem yang korup yang berpotensi melahirnya pemerintahan daerah yang sulit melaksanakan program-program kemajuan daerah tanpa mengakomodir berbagai kepentingan yang telah mengikat dan menarik komitmen pasangan pemenang pilkada. Minimnya transparansi dan akuntabilitas pembiayaan pemilu sebagai ajang kontestasi politik sangat beririsan dengan maraknya praktek korupsi karena berbagai hal, seperti, pertama, biaya politik yang makin mahal akibat oleh semakin berkembangnya fenomena profesionalisasi politik dan kampanye; kedua, semakin rendahnya dukungan finansial dari kelompok akar rumput terhadap para politisi yang berimplikasi pada ketergantungan peserta pemilu kepada donatur swasta dan negara; ketiga, maraknya praktek pembiayaan gelap, dimana sumber penerimaan menjadi tidak jelas; keempat, keinginan kelompok bisnis dalam memberikan dukungan pembiayaan untuk kampanye kepada para calon dengan kompensasi dan harapan akan adanya keuntungan kepada kelompok-kelompok bisnis itu manakala calon-calon tersebut berhasil mendapatkan jabatan- jabatan publik; kelima, ketidaksetaraan akses terhadap sumber-sumber pembiayaan; dan keenam, lemahnya penegakan regulasi atau aturan main, terutama oleh lembaga penyelenggara pemilu dan para pemangku kepentingan terkait, termasuk dalam pengelolaan keuangan di internal partaipartai politik. ${ }^{39}$ Berbagai contoh korupsi politik dan terkait dengan pembiayaan dana kampanye bukanlah sulit, contohnya eperti diketahui publik belum lama ini, ada dugaan sejumlah uang hasil korupsi PLTU Riau-1 yang diduga digunakan pada
Musyawarah Nasional Luar Biasa Partai Golkar Desember 2017. Contoh lainnya adalah, kasus korupsi proyek Hambalang, korupsi Kartu Tanda Pengenal (KTP) Elektronik, korupsi berjamaah di Dewan Perwakilan Rakyat Daerah Provinsi (DPRD) Sumatera Utara, korupsi berjamaah di DPRD Kota Malang, dan sejumlah korupsi yang dilakukan oleh kepala daerah, merupakan bentuk-bentuk korupsi politik yang pernah terjadi. ${ }^{40}$ Apabila dikaitkan dengan perizinan, maka sebagaimana diuraikan dimuka bahwa inflasi memberian izin usaha disektor pertambangan kerapkali meningkat baik itu menjelang akan dilaksanakan pemilu maupun pasca pemilu. ${ }^{41}$

Merujuk regulasi dana kampanye pada Pilkada 2018 diatur dalam Peraturan KPU No. 5 tahun 2017 tentang Dana Kampanye Peserta Pemilihan Gubernur, Bupati dan Wakil Bupati, dan/atau Walikota dan Wakil Walikota. Peraturan KPU No. 5 tahun 2017 menentukan bahwa setiap kandidat kepala daerah diwajibkan membuat Rekening Khusus Dana Kampanye (RKDK) dan laporan keuangan. Sesuai dengan Pasal 13 Peraturan KPU No. 5 tahun 2017, partai politik atau gabungan partai politik yang mengusung kandidat wajib membuka RKDK pada bank umum. RKDK tersebut harus atas nama pasangan Calon dan spesimen tanda tangan harus dilakukan bersama oleh Partai Politik atau Gabungan Partai Politik dan salah satu calon dari Pasangan Calon.

Terdapat tiga laporan keuangan yang harus dibuat oleh kandidat selama masa kampanye, yakni Laporan Awal Dana Kampanye (LADK), Laporan Penerimaan Sumbangan Dana Kampanye (LPSDK), dan Laporan Penerimaan dan Pengeluaran Dana Kampanye (LPPDK). LADK adalah pembukuan yang memuat informasi Rekening Khusus Dana Kampanye, sumber perolehan saldo awal atau saldo pembukaan, rincian perhitungan penerimaan dan

\footnotetext{
39 Mada Sukmajati dan Aditya Perdana, 2018, "Pendahuluan: Pembiayaan Pemilu di Indonesia", dalam Mada Sukmajati dan Aditya Perdana (ed), Pembiayaan Pemilu di Indonesia, Bawaslu, Jakarta, hlm. 6.

$40 \quad$ Ibid, hlm. 7.

41 Tri Hayati, Op. Cit, hlm. 34.
} 
pengeluaran yang diperoleh sebelum pembukaan Rekening Khusus Dana Kampanye, dan penerimaan sumbangan yang bersumber dari kandidat dan/atau partai politik atau gabungan partai politik dan pihak lain. LPSDK adalah pembukuan yang memuat seluruh penerimaan yang diterima Pasangan Calon setelah LADK disampaikan kepada KPU di tingkat daerah. Sedangkan LPPDK adalah pembukuan yang memuat seluruh penerimaan dan pengeluaran Dana Kampanye. Setelah semua tahapan kampanye selesai, LPPDK akan diaudit oleh Kantor Akuntan Publik (KAP) yang ditunjuk oleh KPU di daerah. Masa audit LPPK oleh KAP selama 15 hari terhitung setelah KAP menerima LPPDK. Bentuk perikatan audit dana kampanye adalah sebatas audit kepatuhan. Tujuan audit kepatuhan hanya sebatas untuk menilai kesesuaian pelaporan dana kampanye dengan peraturan perundang-undangan yang mengatur tentang dana kampanye. Tiga instrumen tersebutlah; RKDK, laporan dana kampanye, dan audit dana kampanye, yang menjadi alat bagi penyelenggara pemilu dalam usaha pengungkapan dana kampanye.

Terlepas beberapa positif telah diruaikan diatas, namun sayangnya masih terdapat kekurangan khususnya yang berkaitan upaya menghindari konsekuensi komitmen yang perlu diemban oleh calon peserta pemilu yang kemudian melahirkan investasi politik korup. Hal tersebut antara lain, pertama, yaitu tidak adanya batasan dana kampanye dari sumbangan para calon sendiri. Di satu sisi, banyak sumbangan yang melebihi batasan sumbangan perorangan dan perusahaan akan dilewatkan melalui pintu sumbangan dari para calon ini. Pasangan calon yang memiliki sumber pendanaan dari luar yang besar akan diuntungkan. Di sisi lain, komposisi penyumbang berpotensi menjadi tidak mencerminkan dukungan yang memadai. Sumber sumbangan dari pribadi para calon kepada daerah bisa lebih besar dibanding sumbangan dari pihak lain.

Kedua, pengaturan mengenai penegasan mengenai pembatasan dana kampanye yang bersumber pendanaan dari korporasi swasta dikarenakan untuk mengurangi bentuk investasi politik yang berpotensi melahirkan korupsi lanjutan pasca pemilu. Pengaturan yang dimaksud adalah bentuk pengaturan mengenai proporsionalitas antara komposisi sumbangan korporasi swasta dengan jumlah keseluruhan dana yang terkumpul. Praktek serupa juga pernah menjadi persoalan dalam sistem pemilu di Amerika Serikat. Kasus donasi jutaan dollar dari pengusaha Indonesia James Riady kepada tim sukses Bill Clinton dalam pemilihan presiden Amerika Serikat tahun 1996 atau dugaan kecurangan yang dilakukan oleh sekretaris Partai Republik di negara bagian Florida dan Fox News Channel guna memenangkan George W. Bush dalam pemilihan presiden tahun 2004. ${ }^{42}$ Pengaturan yang demikian ada jelas rentan melahirkan politik balas budi khususnya dalam pemerintahan pasca pemilu. ${ }^{43}$ korupsi pasca pemilu lahir praktek pendanaan kampanye, baik penerimaan maupun pengeluaran, yang menciptakan hubungan koruptif antara penyumbang dan partai politik atau kandidat yang didukungnya maupun pola perilaku koruptif yang terjadi antara peserta pemilu dan voters.

\section{Praktek di Beberapa Negara}

Batasan pengeluaran atau belanja kampanye yang digunakan di berbagai negara pada dasarnya untuk menghindari peran uang yang berlebihan dalam kompetisi politik, mengontrol ketidaksetaraan antar partai atau kandidat dan membatasi ruang lingkup pengaruh yang tidak pantas dan menghindari korupsi politik. Allan Ware menyatakan bahwa, "one means of attempting to stop a 'feeding frenzy' among parties in their

\footnotetext{
42 John Fund, 2004, Stealing Elections, How Voter Fraud Threatens Our Democracy, Encounter Books, San Fransisco, hlm. 33.

43 Secara historis, politik etis lahir sebagai kritik atas politik tanam paksa. Pemerintah kolonial bertanggung jawab atas kesejahteraan pribumi. Gagasan Pieter Brooshooft dan C van Deventer membuka mata Belanda untuk memerhatikan nasib pribumi. Utang budi (een eerschuld) dan panggilan moral dituangkan dalam politik etis, terangkum dalam Trias Politika meliputi irigasi, emigrasi, dan edukasi. Imam Cahyono, Politik Etis Kapitalisme, Kompas, 26 Oktober 2006.
} 
search for funds is to restrict how much they spend on a very costly activity —namely election campaigning." "44 Belanja kampanye yang tidak berbatas dapat memberikan keuntungan yang tidak adil bagi mereka yang memiliki akses ke uang dan pada akhirnya dapat membuat politisi bergantung pada kontributor besar di belakangnya. Untuk memastikan kesetaraan kesempatan bagi kekuatan politik yang berbeda, pembatasan dana kampanye melalui pembatasan belanja menjadi sesuatu hal yang penting.

Apabila merujuk kepada negara-negara Eropa Timur (negara post komunis) pada umumnya pengaturan pembatasan bertitik tolak terhadap pengaturan terhadap sumber dana dan belanja kampanye. Dalam hal sumber dana salah satu yang regulasi paling umum misalnya adalah larangan baik sebagian atau seluruhnya terhadap menggunakan dan memperoleh sumbangan yang bersumber dari luar negeri (dana yang bersumber warga negara asing, pemerintah asing, perusahaan dan organisasi internasional). Sumbangan luar negeri diizinkan dalam beberapa kasus khusus. Peran komunitas internasional dalam restrukturisasi pasca-perang Bosnia Herzegovina menjadi contoh yang menjelaskan mengapa sumbangan asing tertentu diizinkan. ${ }^{45}$ Di Lithuania kecenderungan sumber dana kampanye bersumber dari pelibatan diaspora dalam kegiatan pendanaan partai, sehingga memberikan keuntungan tertentu khususnya kepada sayap kanan, partai nasionalis yang memerintah negara itu. ${ }^{46}$ Selain itu, Sebagian besar negara pasca-komunis telah memilih untuk melarang sumbangan anonim. Namun, Polandia, Bulgaria, dan Lithuania telah mengambil pandangan bahwa sumbangan anonim dalam jumlah yang wajar tidak merusak proses demokrasi. Undang-Undang Pemilu Polandia bahkan menetapkan bahwa donasi anonim harus disimpan di rekening bank terpisah dari sisa dana kampanye. Sedangkan di Bulgaria menetapkan bahwa donasi anonim tidak boleh melebihi $25 \%$ dari total pendapatan pihak. Di Lithuania, satu donasi anonim tidak dapat melebihi USD 25, tetapi total donasi ini tidak terbatas. ${ }^{47}$

Mengenai batasan sumbangan kampanye, sekitar setengah dari negara-negara di kawasan eropa timur telah memperkenalkan batasan sumbangan kepada partai dan/atau kandidat dalam pemilihan. Regulasi yang ada pada pokoknya ditujukan untuk membatasi pengaruh politik dari bisnis besar, temuan yang kerap kali terjadi, menunjukkan bahwa uang cenderung menemukan jalannya ke rekening partai politik melalui sumbangan oleh pihak ketiga, atau melalui pembayaran langsung kepada pihak ketiga. ${ }^{48}$ Selain itu, perihal batasan belanja kampanye, hampir dua pertiga negara-negara eropa timur memiliki regulasi pembatasan belanja kampanye. Namun, sejumlah ahli berpendapat bahwa beberapa negaranegara tertentu dikawasan eropa timur menjelaskan lagi bahwa pembatasan belanja kampanye ini tidak diatur. ${ }^{49}$ Beberapa negara seperti BosniaHerzegovina, Republik Ceko, dan Slovakia bahkan telah memilih untuk melarang belanja iklan politik sebagai upaya untuk melemahkan pengaruh adanya sumber keuangan yang besar. ${ }^{50}$

Berbeda dengan apa yang berkembang di kawasan eropa timur, di Meksiko, KPU Meksiko mendapat mandat mengelola kampanye di media sehingga setiap partai politik peserta pemilu

\footnotetext{
44 Alan Ware, 1995, Political Party and Party Systems, Oxford University Press, London., hlm. 227.

45 Jānis Ikstens, et. al., Political Finance in Central Eastern Europe: An Interim Report, Österreichische Zeitschrift für Politikwissenschaft, Vol. 31, No. 1, 2002, hlm. 21.

$46 \quad$ Ibid, hlm. 22.

47 Vít Šimral, 2011, The Funding and Oversight of Political Parties and Election Campaigns in East Central Europe, Open Society Foundations, Prague, hlm. 44 - 45.

48 Elin Falguera, Samuel Jones, dan Magnus Ohman, 2014, Funding of Political Parties and Election Campaigns: a Handbook on Political Finance, International Institute for Democracy and Electoral Assistance, Stromsborg, hlm. 287-288.

49 Julio Bacio Terracino dan Yukihiko Hamada, 2014, Financing Democracy: Supporting Better Public Policies and Preventing Policy Capture, OECD, Washington, hlm. 18 .

50 Vít Šimral, Op. cit., hlm. 55.
} 
memiliki iklan di media dengan durasi dan slot yang sama. Pembatasan juga dapat dilakukan dengan membatasi pengeluaran kampanye yang diperbolehkan hanya untuk kegiatan tertentu. ${ }^{51}$ Di Inggris misalnya melalui The Corrupt and Illegal Practices Act 1883 (CIPA) sebagai fondasi perkembangan demokrasi Westminster, mengintroduksi pembatasan pengeluaran kampanye yang diperbolehkan di tiap konstituensi CIPA diperluas dan direvisi dalam Political Parties, Elections, and Referendum Act 2000. Pada umumnya di negara-negara Britania Raya, pembelian jam tayang media untuk iklan politik dilarang. Namun, Kantor Berita British Broadcasting Corporation (BBC) (menurut konvensi) dan televisi independen tertentu dan penyiar radio (menurut undangundang) menyediakan air time gratis kepada pihak yang berkualifikasi pada waktu pemilihan dan pada tanggal-tanggal penting lainnya dalam kalender politik. ${ }^{52} \mathrm{Hal}$ ini bukan merupakan bantuan langsung dari negara hanya karena diberikan cuma-Cuma, melainkan dimaksudkan untuk menjaga kompetisi politik. Dalam pengaturan saat ini, setiap partai yang mengajukan kandidat di seperenam kursi yang diperebutkan pada pemilihan dianggap baru memenuhi syarat untuk waktu siaran, dan saluran TV juga dialokasikan serangkaian slot siaran untuk kampanye partai. ${ }^{53}$

Berbeda hal nya dengan Polandia, batasan pada iklan media berbayar selama pemilihan parlemen pertama kali diperkenalkan pada pemilu 1993. Regulasi di Polandia menentukan bahwa waktu yang dialokasikan untuk iklan berbayar tidak boleh melebihi 15 persen dari total waktu penyiaran gratis yang dialokasikan untuk partai tertentu. Namun, sebuah undang-undang tahun
2001 menghapuskan batasan-batasan spesifik ini. Menurut peraturan baru, pengeluaran oleh pihak/ kandidat pada kegiatan iklan untuk ras lokal (atau mereka yang menyerupai mereka dalam cara dan mode, termasuk publikasi pers) tidak dapat melebihi 80 persen dari batas nasional. Namun, peraturan tahun 1993 masih berlaku untuk pemilihan presiden. Masing-masing pihak dapat menyiarkan program pemilu berbayar antara hari ke-15 sebelum pemungutan suara dan hari terakhir kampanye pemilihan. Namun, total waktu yang ditetapkan untuk penyiaran berbayar tidak dapat melebihi 15 persen dari waktu yang diberikan oleh komite yang diberikan untuk menyiarkan program pemilihan bebas. ${ }^{54}$

Situasi pengaturan pembatasan dana kampanye di negara-negara Amerika Latin pada umumnya konsisten dengan tren global. Hampir semua negara Amerika Latin telah memperkenalkan pelarangan penggunaan sumber-sumber pembiayaan tertentu dan sebagian besar memberlakukan batasan dalam kaitannya dengan jumlah sumbangan, Hanya El Salvador yang tidak menetapkan batasan dalam hal ini. Di antara larangan, yang paling umum ada hubungannya dengan sumbangan dari pemerintah asing, lembaga, dan individu (sebagian besar negara, kecuali El Salvador) ${ }^{55}$, kontraktor pemerintah (misalnya Argentina dan Bolivia), dan sumber anonim (lebih dari separuh negara, termasuk Kosta Rika, Honduras, dan Meksiko). Sama pentingnya adalah bahwa beberapa negara di kawasan ini (termasuk Argentina, Honduras, Meksiko, Paraguay, dan Kosta Rika) telah melarang sumbangan oleh badan hukum. Berbagai keterbatasan dan batasan kontribusi dari individu telah diperkenalkan dalam

Kevin Casas dan Zamora Daniel Zovatto, 2016, The Cost of Democracy: Essays on Political Finance in Latin America, Inter-American Dialogue, Washington, hlm. 56

52 Michael Pinto-Duschinsky dan Alexander Postnikov, 1999, Campaign Finance In Foreign Countries: Legal Regulation And Political Practices, International Foundation for Election Systems, hlm. 6-7.

53 Elin Falguera, Samuel Jones, dan Magnus Ohman, Op. cit., hlm 312.

54 Eric Avis Claudio Ferraz Frederico Finan Carlos Varjão, 2017, Money and Politics: The Effects of Campaign Spending Limits on Political Competition and Incumbency Advantage, National Bureau of Economic Research, Cambridge, hlm. 16-18.

55 Legislativa, T., "Asamblea Legislativa De El Salvador | Más Cerca De Tí / UU Partai Politik 2013”, diakses https://www.asamblea.gob.sv/ decretos/details/249, diakses 20 Desember 2019. 
kasus Argentina, Bolivia, Brasil, Kolombia, Chili, Ekuador, Guatemala, Meksiko, Paraguay, Peru, dan Uruguay. ${ }^{56}$

Pembatasan semacam itu pada sumbersumber pembiayaan swasta ditujukan untuk mengatasi dua risiko pertama yang dijelaskan di atas dengan meminimalkan peluang untuk membeli pengaruh oleh donor yang kuat atau kontroversial. Seperti yang terjadi dengan tindakan pengaturan ketat lainnya, batasan pada kontribusi memerlukan regulasi dan penegakkan yang ketat dalam pelaksanaannya, perlunya sistem yang ekstensif dalam hal pelapor dan kewenangan mengaudit segala sumber dana kampanye yang digunakan oleh para kandidat menjadi tantangan yang telah terbukti dilaksanakan bahkan di negara demokrasi yang paling maju. ${ }^{57}$
Pembatasan dana kampanye diberbagai negara memiliki formulasi yang berbeda-beda namun mengalami masalah yang sama, apabila terlalu pembatasannya tinggi, maka dapat mengarah pada hasil yang merugikan. Tindakan kejam untuk sepenuhnya melarang kontribusi swasta, seperti yang berlaku di Perancis sebelum 1988 dan di India dari 1969 hingga 1985, akhirnya mendorong praktik koruptif yang sangat buram. ${ }^{58}$ Jadi tidak mengherankan bahwa banyak demokrasi, terutama di Eropa Barat, enggan untuk menetapkan kontrol yang komprehensif pada sumbangan dana kampanye, sebaliknya memilih untuk membatasi beban keuangan donor swasta dengan cara lain, seperti sistem pembiayaan publik, kampanye pemilihan singkat, dan pembatasan berat pada iklan pemilihan. Berikut rekapitulasi pola pembatasan dana kampanye di beberapa negara.

Tabel 1.

Pola Pembatasan Dana Kampanye di Beberapa Negara

\begin{tabular}{|c|c|c|c|c|c|c|}
\hline Negara & $\begin{array}{l}\text { Peraturan dalam } \\
\text { Undang-Undang }\end{array}$ & $\begin{array}{l}\text { Peng } \\
\text { umuman dan } \\
\text { atau Laporan }\end{array}$ & $\begin{array}{l}\text { Pembatasan } \\
\text { Sumbangan } \\
\text { Masyarakat }\end{array}$ & $\begin{array}{l}\text { Pembatasan } \\
\text { Sumbangan } \\
\text { Perusahaan }\end{array}$ & $\begin{array}{l}\text { Pembatasan } \\
\text { Sumbangan Luar } \\
\text { Negeri }\end{array}$ & $\begin{array}{l}\text { Pembatasan } \\
\text { Pengeluaran/Belanja } \\
\text { Kampanye }\end{array}$ \\
\hline Albania & Ada & Tidak Ada & Tidak Ada & Tidak Ada & Ada(Dibatasi) & Tidak Ada \\
\hline Austria & Ada & Ada & Tidak Ada & Tidak Ada & Tidak Ada & Tidak Ada \\
\hline Belgia & Ada & Ada & Ada & Ada (Dilarang) & Tidak Ada & Ada \\
\hline Kroasia & Ada & Ada & Tidak Ada & Tidak Ada & Tidak Ada & Tidak Ada \\
\hline Rep Ceko & Ada & Ada & Tidak Ada & Tidak Ada & Ada (Dilarang) & Tidak Ada \\
\hline Denmark & Ada & Tidak Ada & Tidak Ada & Tidak Ada & Tidak Ada & Tidak Ada \\
\hline Estonia & Ada & Ada & Tidak Ada & Tidak Ada & Ada(Dibatasi) & Tidak Ada \\
\hline Finlandia & Tidak Ada & Ada & Tidak Ada & Tidak Ada & Tidak Ada & Tidak Ada \\
\hline Perancis & Ada & Ada & Ada & Ada (Dilarang) & Ada(Dibatasi) & Ada \\
\hline Georgia & Ada & Ada & Ada & Ada(Dibatasi) & Ada(Dibatasi) & Ada \\
\hline Jerman & Ada & Ada & Tidak Ada & Tidak Ada & Ada(Dibatasi) & Tidak Ada \\
\hline Yunani & Ada & Ada & ada & Ada(Dibatasi) & Tidak Ada & Ada \\
\hline Hungaria & Ada & Ada & Tidak Ada & Tidak & Ada(Dibatasi) & Ada \\
\hline Irlandia & Ada & Ada & Tidak Ada & Tidak Ada & Tidak Ada & Ada \\
\hline Italia & Ada & Ada & Tidak Ada & Tidak Ada & Tidak Ada & Ada \\
\hline Latvia & Ada & Ada & Ada & Ada(Dibatasi) & Ada(Dilarang) & Tidak Ada \\
\hline Lithuania & Ada & Ada & Tidak Ada & Ada(Dibatasi) & Ada(Dibatasi) & Ada \\
\hline
\end{tabular}

56 Kevin Casas dan Zamora Daniel Zovatto, Op.cit., hlm. 77.

57 Kendala ini yang pada umumnya dihadapi oleh Komisi Pemilihan Federal Amerika Serikat (FEC) ketika menegakkan pembatasan kontribusi kampanye yang diperkenalkan oleh Federal Election Commission Act of 1974. [Kenneth A. Gross, "The Enforcement of Campaign Finance Rules: A System in Search of Reform", dalam Anthony Corrado, Thomas E. Mann, Daniel R. Ortiz, dan Trevor Potter (eds), 1997 Campaign Finance Reform: A Sourcebook, (Washington D. C.: Brookings Institution Press), hlm. 310-314.

58 Richard Levush, 1995, Report for Congress: Campaign Financing of National Elections in Selected Foreign Countries, Library of Congress, Law Library, Washington D.C., hlm. 119 dan Piere Avril, 'Regulation of Political Finance in France', dalam Alexander Herman dan R. Shiratori, 1994, Comparative Political Finance among the Democracies, Westview Press, Boulder. hlm 85-95. 


\begin{tabular}{|c|c|c|c|c|c|c|}
\hline Luxembourg & Ada & Tidak Ada & Tidak Ada & Tidak Ada & Tidak Ada & Tidak Ada \\
\hline Moldova & Ada & Ada & Tidak Ada & Tidak Ada & Ada (Dilarang) & Tidak Ada \\
\hline Belanda & Ada & Ada & Tidak Ada & Tidak Ada & Tidak Ada & Tidak Ada \\
\hline Norwegia & Tidak Ada & Ada & Tidak Ada & Tidak Ada & Tidak Ada & Tidak Ada \\
\hline Polandia & Ada & Ada & Tidak Ada & Tidak Ada & Ada (Dilarang) & Tidak Ada \\
\hline Portugal & Ada & Ada & Ada & Ada(Dibatasi) & Ada(Dibatasi) & Ada \\
\hline Romania & Ada & Ada & Ada & Ada(Dibatasi) & Ada(Dibatasi) & Tidak Ada \\
\hline Rusia & Ada & Ada & Ada & Tidak Ada & Ada (Dilarang) & Ada \\
\hline Slovakia & Ada & Ada & Tidak Ada & Tidak Ada & Ada (Dilarang) & Ada \\
\hline Slovenia & Ada & Ada & Ada & Ada(Dibatasi) & Ada (Dilarang) & Tidak Ada \\
\hline Spanyol & Ada & Ada & Ada & Ada(Dibatasi) & Ada (Dilarang) & Tidak Ada \\
\hline Swedia & Tidak Ada & Ada & Tidak Ada & Tidak Ada & Tidak Ada & Tidak Ada \\
\hline Yugoslavia & Ada & Ada & Ada & Ada(Dibatasi) & Ada (Dilarang) & Ada \\
\hline Swiss & Tidak Ada & Tidak Ada & Tidak Ada & Tidak Ada & Tidak Ada & Tidak Ada \\
\hline Ukraina & Tidak Ada & Ada & Ada & Tidak Ada & Ada (Dilarang) & Ada \\
\hline Inggris & Ada & Ada & Tidak Ada & Tidak Ada & Tidak Ada & Ada \\
\hline
\end{tabular}

Sumber: Diolah oleh Penulis, tahun tidak dicantumkan penulis. ${ }^{59}$

\section{Optimalisasi Pembatasan Dana Kampanye}

Sekurang-kurangnya terdapat tiga tujuan pengaturan dana kampanye dalam Pemilu.

Pertama, bila dirumuskan menggunakan bahasa secara negatif, bahwa pengaturan dana kampanye dimaksudkan untuk mencegah dominasi satu atau dua partai politik atau calon yang memiliki dana yang besar dalam menyampaikan visi, misi dan program. Sedangkan apabila diuraikan dalam bahasa positif, pengaturan dana kampanye dimaksudkan untuk menjamin sumber informasi mengenai partai dan calon yang beragam kepada pemilih. ${ }^{60}$ Tujuan kedua diperlukannya pengaturan dana kampanye berkaitan dengan upaya mencegah jangan sampai penyandang dana kampanye mendikte kebijakan yang akan diambil oleh kandidat kepala daerah. Atau dengan kata lain, pengaturan dana kampanye dimaksudkan untuk menjamin agar kandidat kepala daerah lebih memperhatikan aspirasi dan kepentingan konstituen dalam membuat dan melaksanakan keputusan di lembaga eksekutif.
Tujuan ketiga adalah mencegah jangan sampai hanya orang yang kaya tetapi tak berkualitas sajalah yang dapat menjadi calon yang dipilih atau dimaksudkan untuk menjamin agar seseorang yang tidak kaya tetapi memiliki integritas dan kapasitas sebagai kandidat kepala daerah. ${ }^{61}$ Berdasarkan serangkaian tujuan tersebut, menunjukan bahwa unsur finansial akan cukup memberi peluang dalam rangka pemenangan kandidat. Karena unsur tersebut dapat dikonversi menjadi berbagai alat untuk pemenuhan kebutuhan kampanye. Dengan terpenuhinya kebutuhan kampanye maka peserta pemilu dapat melakukan kampanye dengan lebih intens dan masif. Dengan demikian peluang peserta yang dapat porsi lebih mengkampanyekan dirinya dengan lebih intens dan massif akan mendapat peluang lebih karena para peserta pemilu ini dapat mempromosikan dirinya lebih dari pada peserta pemilu yang lainnya.

Apabila merujuk kepada Peraturan KPU No. 5 Tahun 2017, maka aspek yang diatur menyangkut

59 Marcin Walecki, Op. Cit., hlm. 3., Michael Pinto-Duschinsky dan Alexander Postnikov, 1999, Op. cit., hlm 6-7., Richard Levush, Op. cit., hlm. 119., Kevin Casas dan Zamora Daniel Zovatto, Op.cit., hlm. 56.

60 Para pemilih dalam sistem politik demokrasi harus diberikan informasi yang lengkap mengenai berbagai alternatif kebijakan publik bagi kesejahteraan rakyat dari berbagai peserta Pemilu ataupun para calon. Kalau alternatif kebijakan itu hanya datang dari satu atau dua partai ataupun calon, maka para pemilih sesungguhnya tidak memilih melainkan pilihan sudah dibuatkan bagi mereka. Dalam pemilihan umum, para pemilih haruslah dapat memilih satu partai/calon dari sekian banyak alternatif berdasarkan hasil penilaian terhadap berbagai alternatif kebijakan yang ditawarkan oleh banyak partai politik. [Didik Supriyanto (Editor), Lia Wulandari, Armanda Pransiska, dan Catherine Natalia, Dana Kampanye Pilkad......Op. cit., hlm. 27.

$61 \quad$ Ibid, hlm. 28. 
sumber dana kampanye, wujud dana kampanye, batas maksimal sumbangan dari berbagai pihak yang diizinkan memberikan sumbangan, jumlah maksimal pengeluaran kampanye, persyaratan tentang identitas penyumbang dan asal-usul sumbangan, tata cara pembukuan dana kampanye yang harus terpisah dari pembukuan penerimaan dan pengeluaran partai untuk kegiatan non kampanye, pencatatan penerimaan dalam bentuk uang pada rekening khusus dana kampanye, mekanisme pelaporan penerimaan dan pengeluaran kampanye, persyaratan Kantor Akuntan Publik (KAP) yang dapat ditunjuk oleh KPU untuk mengaudit laporan penerimaan dan pengeluaran dana kampanye, mekanisme kerja KAP, prosedur audit, larangan, dan sanksi. Dua asas yang biasanya mendasari pengaturan dana kampanye pemilihan umum, yaitu transparansi dan keadilan. Pertanyaannya, apakah ketiga tujuan sebagaimana diatas di atas dapat dicapai dengan pengaturan dana kampanye pada UU Pilkada saat ini?

Apabila ditinjau lebih dalam, ketentuan UU Pilkada saat ini telah memiliki materi pokok pengaturan dana kampanye yang lazim dipraktikkan di beberapa negara demi menjamin penerapan prinsip transparansi dan akuntabilitas penggunaan dana kampanye. Prinsip transparansi mengharuskan partai politik peserta pemilu dan calon bersikap terbuka terhadap semua proses pengelolaan dana kampanye, khususnya, dalam pemasukan atau pendapatan serta pengeluaran atau belanja. ${ }^{62}$ Sejumlah kewajiban harus dilakukan oleh partai politik dan calon, seperti membuat daftar penyumbang, daftar pendapatan, daftar belanja, neraca dan lain-lain. Tujuan membuat daftar penyumbang, daftar pendapatan dan daftar belanja, neraca, dan lain-lain adalah untuk menguji prinsip akuntabilitas, yaitu memastikan tanggung jawab partai politik dan calon dalam proses menerima dan membelanjakan dana kampanye sesuai etika dan tidak melanggar peraturan. ${ }^{63}$

Selain itu, prinsip utama lainnya sebagai pembatasan dana kampanye dari sisi belanja adalah penerapan prinsip keadilan dan kesetaraan di antara partai peserta pemilu dan calon. Prinsip ini menjadi dasar untuk menciptakan kesempatan yang sama di antara para partai politik peserta pemilu dalam berkompetisi memperebutkan suara pemilih. Itu artinya hasil pemilu tidak ditentukan oleh siapa yang memiliki dana paling banyak, melainkan oleh kinerja dan kreativitas partai politik peserta pemilu dan calon dalam melakukan kampanye. Prinsip ini merupakan landasan untuk menciptakan persaingan sehat karena masing-masing partai politik dan calon memiliki peluang yang sama untuk berkampanye dalam rangka meyakinkan pemilih. ${ }^{64}$ Sehingga, kerangka hukum yang seharusnya dapat memuat prinsip-prinsip tersebut, seharusnya memenuhi kriteria sebagai berikut: Pertama, adanya sistem yang mengizinkan atau menyediakan ruang untuk mendukung kampanye yang kompetitif. Kedua, sistem yang dapat menjaga peluang bagi semua penduduk untuk berpartisipasi secara sama. Ketiga, adanya sistem yang terbuka untuk memunculkan partisipasi. Keempat adanya, sistem yang dapat mencegah korupsi dengan membebaskan kandidat, partai, dan calon terpilih dari pengaruh yang tidak diinginkan dari kontributornya. Kelima, adanya sistem yang dapat membebaskan pemilih dari tekanan kandidat ataupun partai dari iming-iming dukungan keuangan (vote buying).

Sejauh ini, UU No 1 Tahun 2015 jo UU No 8

62 Elin Falguera, Samuel Jones, dan Magnus Ohman, Op.cit., hlm. 316.

63 Australia misalnya lebih mengedepankan transparansi dalam pengaturan dana kampanye. Karena itu partai politik atau calon dapat menerima dana kampanye dari siapa saja, berapapun besarnya, dan berapapun jumlah pengeluarannya sepanjang semua penerimaan dan pengeluaran itu diumumkan kepada publik melalui KPU Australia (dengan mengisi formulir yang sudah disediakan). Amerika Serikat pada pihak lain mengedepankan transparansi dan keadilan dalam pengaturan dana kampanye. Karena itu, calon tidak saja diberi memilih sumber dana kampanye (menerima dari negara sesuai dengan jumlah dana kampanye yang dihimpun, atau, sepenuhnya berasal dari upaya sendiri) tetapi juga diwajibkan mematuhi batas maksimal sumbangan dan batas maksimal jumlah pengeluaran. Komisi Pemilu Amerika pada tingkat Federal sama sekali tidak menangani penyelenggaraan pemilihan umum melainkan mengawasi dan menegakkan pengaturan dana kampanye. [Eric Avis Claudio Ferraz Frederico Finan Carlos Varjão, Op. Cit., hlm. 23.

64 Burhanuddin Muhtadi, Op. Cit., hlm. 63. 
Tahun 2015 jo UU No 10 Tahun 2016 menyebutkan bahwa tujuh metode kampanye: a) pertemuan terbatas; b) pertemuan tatap muka/dialog; c) debat publik/debat terbuka antarpasangan calon; d) penyebaran bahan kampanye kepada umum; e) pemasangan alat peraga; f) iklan media massa cetak dan media massa elektronik; dan atau g) kegiatan lain yang tidak melanggar peraturan perundangundangan. Yang baru dari undang-undang ini adalah ketentuan bahwa, kampanye huruf (c), (d), (e), dan (f) difasilitasi oleh KPU yang didanai APBN. Jadi, pasangan calon kepala daerah hanya membiayai kampanye pertemuan terbatas dan pertemuan tatap muka dan dialog. Namun ketentuan-ketentuan yang mengatur dana kampanye dalam UU No. 1/2015 juncto UU No. 8/2015 masih sangat terbatas, baik dalam jumlah pasal dan ayat maupun dalam kandungan materi pengaturan. Dalam hal pengaturan dana kampanye, terdapat beberapa perbedaan antara UU Pilkada yang baru (UU No. 10 Tahun 2016) dengan UU Pilkada sebelumnya (UU No. 8 Tahun 2015) seperti khususnya Pasal 74 ayat (5) yang terdapat kenaikan batasan sumbangan dan tidak adanya batasan dana kampanye dari sumbangan pasangan calon. Tiadanya ketentuan yang menegaskan adanya batasan sumbangan dana kampanye pasangan calon yang tidak boleh melebihi batas pembiayaan kampanye sebagaimana ditentukan peraturan ini menunjukan bahwa regulasi saat ini masih belum optimal. Sanksi yang saat ini diatur didalam Pasal 53 Peraturan KPU No. 5 Tahun 2017 belum sepenuhnya relevan, dikarenakan sesungguhnya adanya pelanggaran pembatasan dana kampanye berarti adanya kelebihan dana dari pembatasan yang seharusnya ditaati, sehingga ancaman sanksi wajib menyerahkan kelebihan dana kampanye tersebut ke kas negara menjadi hal yang lebih relevan.

Pada Pilkada tahun 2018, disadari bahwa dana kampanye rentan dilanggar pasangan calon pilkada. Pelanggaran dana kampanye ini banyak dilatarbelakangi pada mahalnya biaya politik pada saat ini. Faktor inilah yang menjadi perhatian penyelenggara pemilu, baik itu Komisi Pemilihan Umum (KPU) dan Badan Pengawas Pemilu (Bawaslu). Sebab besaran dana kampanye hingga saat ini masih diyakini banyak pihak masih menjadi faktor penentu (determinan) kemenangan dalam pilkada, atau dalam pemilu. Lahirnya UU No. 10 Tahun 2016 tentang Pemilihan Kepala Daerah sejatinya telah mengatur tegas pembatasan dana kampanye. Dalam Pasal 74 ayat (9) Pembatasan dana kampanye paslon ditetapkan oleh KPU Provinsi dan KPU Kabupaten/Kota, dengan mempertimbangkan jumlah pemilih, cakupan atau luas wilayah, dan standar biaya daerah.

Pembatasan dana kampanye juga berlaku dalam sumbangan perseorangan dan perusahaan. Masalahnya, meski aturan sudah sedemikian tegas dibuat, indikasi pelanggaran dana kampanye tetap saja ditemukan sejumlah pihak. Dengan alasan mahalnya biaya politik ini, tak sedikit para kandidat yang maju pada pemilu atau pilkada pada akhirnya nekat melanggar ketentuan dalam laporan penerimaan dan pengeluaran dana kampanye (LPPDK) maupun laporan penerimaan sumbangan dana kampanye (LPSDK). Seperti halnya terjadi dalam pemilihan bupati di Kabupaten Lembata pada tahun 2017. Ketika itu kasus sumbangan dana kampanye perseorangan yang ditaksir mencapai ratusan juta rupiah. Berdasarkan pernyataan Panitia Pengawas Pemilihan (Paswaslih) setempat yang mengacu pada LPSDK, menunjukkan paket Sunday (Eliazer Yentji Sunur - Thomas Ola) mendapat sumbangan perseorangan sebesar Rp170 Juta. Sementara paket Titen (Herman Wutun-Vian Burin) mendapatkan sumbangan sebesar Rp250 juta. ${ }^{65}$

Hal semacam itu sebenarnya sudah terurai dilihat pada tahun 2015, seperti yang dilaporkan oleh lembaga pemantau pemilu, Jaringan Pendidikan Pemilih Untuk Rakyat (JPPR). Pada pilkada

65 Ambaranie Movanita, “Abai Soal Dana Kampanye, Calon Kepala Daerah Bisa Digugurkan” Kompas, 17 Maret 2018. 
serentak di tahun itu JPPR mengaku menemukan dugaan manipulasi sumbangan dana kampanye di tiga daerah pemilihan yang menyelenggarakan pilkada serentak di tahun itu. JPPR mengaku telah menemukan dana sumbangan melebihi batas di Kabupaten Seluma, pola pemecahan jumlah sumbangan di Kota Balikpapan, dan adanya identitas penyumbang fiktif Kota Tangerang Selatan. Temuan di ketiga daerah ini, diakui pihak JPPR memiliki kesamaan dengan pola yang riskan terjadi di semua wilayah di Indonesia. ${ }^{66}$

Mengenai masih kerap munculnya pelanggaran sumbangan kampanye ini juga selalu dibersamaan dengan permasalahan ketidakjelasan sumber sumbangan dana kampanye pasangan calon, baik perorangan maupun perusahaan yang nyatanya selalu ditemukan dari pilkada ke pilkada. Sayangnya, masalah tersebut, hanya sebagian pengawas pemilu yang mampu mempublikasikan data tersebut. Ketidakjelasan yang kerap kali muncul meliputi identitas pemberi dana, alamat penyumbang, nomor kontak penyumbang, nomor pokok wajib pajak, serta ketidakjelasan sumber pemasukan penyumbang. Padahal, dalam UU No. 1 Tahun 2015 Pasal 76 dijelaskan bahwa partai politik dan/atau gabungan partai politik yang mengusulkan calon dan calon perseorangan dilarang menerima sumbangan atau bantuan lain untuk kampanye yang berasal dari penyumbang atau pemberi bantuan yang tidak jelas identitasnya. Lebih lanjut, dalam ayat (3) dan (4) dikatakan, jika terbukti melanggar ketentuan, maka akan ada sanksi berupa pembatalan calon yang diusulkan. Sehingga kasus diskualifikasi calon bupati Sinjai, Sabirin Yahya-Andi Mahyoto, oleh Komisi Pemilihan Umum Kabupaten Sinjai karena terlambat memasukkan laporan penerimaan dan pengeluaran dana kampanye (LPPDK) adalah langkah nyata keberanian penyelenggara pemilu.

Apabila merujuk kepada Pasal 39 Peraturan KPU No. 5 Tahun 2017 bahwa jenis audit yang digunakan adalah sekedar audit kepatuhan, padahal apabila kemudian diatur penggunaan metode pemeriksaan atau audit investigasi, maka akan memperjelas siapa pemodal di balik kandidat. Tanpa audit investigasi, maka akan terdapat upaya kandidat untuk dapat memanipulasi laporan sumber dana kampanyenya. Artinya, dana kampanye yang dilaporkan tidak mencerminkan kondisi sebenarnya. Padahal, tujuan utama pengaturan mengenai audit kampanye ini adalah agar tidak digunakannya uang haram.

Selain itu, dengan memberikan kewenangan kepada Bawaslu untuk melakukan pengawasan melekat dan penelusuran terhadap keabsahan sumber dana kampanye merupakan sebuah keniscayaan. Sehingga Jika terjadi kejanggalan, maka Bawaslu dapat memberikan rekomendasi kepada KPU untuk menjatuhkan sanksi. Maanfaat lainnya, analisis Bawaslu bisa dijadikan sebagai data pembanding dengan hasil audit KAP. Arah pengaturan mengenai pengawasan sumbangan dari perseorangan dan badan usaha merupakan hal yang sangat penting, mengingat adanya potensi terjadinya pelanggaran hukum dengan munculnya hubungan antara uang dan keputusan politik. Oleh karena itu, peraturan dana kampanye harus menerapkan beberapa ketentuan dasar untuk mencegah konflik kepentingan, mencegah prasangka terhadap kegiatan partai politik dan calon, menjamin transparansi asal susul sumbangan dan mencegah sumbangan yang dirahasiakan. Sehingga peraturan harus menjamin kemandirian partai politik dan calon anggota legislatif (terpilih) dan calon pejabat eksekutif (terpilih) dalam mengambil kebijakan dan keputusan pada saat mendudukui jabatan pasca pemilu.

Selain perlunya audit yang tidak hanya sekedar kepatuhan, adanya kontrol audit dana kampanye menjadi sudut penting tersendiri. Hingga saat ini belum diatur adanya kontrol atas pelaksanaan audit dana kampanye yang dilakukan oleh KAP. Selama ini, kontrol terhadap para KAP di seluruh

${ }_{66}$ M. Afifuddin, et. al., Op. cit., hlm. 21. 
Indonesia dilakukan oleh Departemen Keuangan melalui Pegawai Pemerintah dengan Perjanjian Kerja (PPPK) dan Institut Akuntan Publik Indonesia (IAPI) selaku satu-satunya asosiasi profesi yang menaungi para akuntan publik Indonesia. Namun, kenyataannya, belum ada mekanisme kontrol atas pelaksanaan audit dana kampanye khususnya pada pelaksanaan pilkada. Sehingga apabila pengawasan kinerja audit semacam itu masih lemah, maka potensial berujung pada dampak buruk. Dampak itu, baik terhadap profesi akuntan publik dan KAP maupun terhadap akuntabilitas hasil audit dana kampanye. Selain berpotensi menyuburkan KAP dan akuntan publik yang belum berkompeten dalam mengaudit dana kampanye, hasil audit juga dikhawatirkan tidak memenuhi standar dan tidak dilakukan dengan profesional. Hasil audit dana kampanye pun kemudian hanya sebagai "syarat" dana kampanye disebut transparan dan akuntabel tetapi mengabaikan hal-hal substansial di dalamnya.

Peraturan KPU No. 5 Tahun 2017 yang mengatur mengenai pembatasan dana kampanye kepala daerah nyatanya tidak sepenuhnya sesuai dengan tujuan pembatasan dana kampanye sendiri yaitu untuk menjaga agar pasangan calon terpilih tetap mengemukakan kepentingan pemilih daripada kepentingan para penyumbang dalam membuat kebijakan. Selain itu, untuk menghindari jor-joran pengumpulan dan pengeluaran dana kampanye sebagaimana sering terjadi pada pilkada sebelumnya. sebagai contoh, anomali semacam itu tercermin dalam Pemilihan Umum Gubernur dan Wakil Gubernur DKI Jakarta misalnya, KPU DKI Jakarta menetapkan bahwa batasan Dana Kampanye adalah sebesar 203 Miliar, namun kenyataannya Pasangan Pemenang Gubernur dan Wakil Gubernur DKI Jakarta yaitu Anies Baswedan dan Sandiaga Uno mengaku hanya menghabiskan dana kampanye sebesar Rp 64,4 Miliar. Selain itu Dana kampanye di Jawa Barat tahun 2013 ditetapkan batasan biaya kampanye sebesar
Rp 172 miliar, sedangkan pasangan pemenang pilkada Ahmad Heryawan-Dedy Mizwar hanya menghabiskan total Rp 25 miliar. $^{67}$ Oleh karena itu, pembatasan harus juga dilakukan dari sisi pengeluaran atau belanja. Sebab, dengan cara ini partai politik peserta pemilu atau calon tidak lagi berusaha menggalang dana kampanye sebanyak mungkin karena mereka tahu dana tersebut tidak bisa digunakan jika dikumpulkan melampaui batas yang diperbolehkan. Namun apabila merujuk kepada pengaturan mengenai pembatasan dana kampanye kepala daerah saat ini belum sepenuhnya mampu membatasi dana kampanye itu sendiri. Pengaturan yang ada saat ini belum mampu menjangkau lingkaran praktik silang korupsi yang dilakukan oleh kandidat calon kepala/wakil kepala daerah dan pihak donaturnya. Besarnya dana yang dibutuhkan untuk kampanye pilkada, membuat pasangan calon berpotensi menerima aliran dana dari berbagai pihak donatur. Beberapa dana potensial yang sering dimanfaatkan kandidat antara lain dana pribadi kandidat yang terkadang berasal dari korupsi silang antara kandidat dan pengusaha.

Selain itu, bantuan dan dari pengusaha/ badan usaha yang sering mengerjakan proyek pemerintah dan, pemanfaatan dana hibah, bantuan sosial dan bantuan keuangan dari APBD masih menjadi objek pengaturan yang perlu kembali diperketat. Regulasi pilkada saat ini secara implisit tidak mengatur batasan-batasan pengelolaan APBD menjelang pemilukada agar tidak dimanfaatkan oleh calon petahana. Dalam pasal 71 ayat $3 \mathrm{UU}$ No. 10 Tahun 2016 dan Pasal 89 ayat 2 Peraturan KPU 5 tahun 2017 mengatur, selama enam bulan menjelang penetapan calon kepala daerah dilarang untuk menggunakan kewenangan, program, dan kegiatan yang mengguntugkan atau merugikan salah satu pasangan calon. Namunnyartana pasal itu sulit ditegakkan karena tidak ada tolok ukur atau batasan untuk kepala daerah bahwa dalam menjalankan kewenangan, program dan kegiatan

\footnotetext{
${ }_{67}$ Alsadad Rudi, “Sandiaga Habiskan Rp 108 Miliar Selama Pilkada DKI”, Kompas, 18 Maret 2017.
} 
telah menguntungkan atau merugikan salah satu pasangan calon.

Permasalahan dana kampanye seperti dipaparkan di atas, tentu merupakan bagian yang harus menjadi fokus pengawasan Bawaslu, dengan berbagai tingkat kompleksitas dan kerumitan yang harus dihadapi. Hal tersebut lebih disebabkan karena soal seputar dana kampanye merupakan permasalahan yang klasik karena selalu muncul dalam setiap momentum politik, baik pada pemilu gubernur dan wakil gubernur, bupati dan wakil bupati serta pemilu wali kota dan wakil walikota.

\section{Kesimpulan}

Merujuk kepada rumusan masalah pertama, maka persoalan penting tentang pengaturan pendanaan kampanye tidak hanya cukup untuk melihat akuntabilitas pemilu dan/atau akuntabilitas keuangan peserta pemilu. Jauh lebih penting lagi bahwa akibat dari pengaturan pendanaan kampanye yang tidak ketat tentang larangan pihak swasta sebagai penyumbang dana kampanye akan berakibat kepada terjadinya penanaman modal politik balas budi/investasi politik yang korup antara patai politik, calon peserta pemilu dan pihak lainnya. Karena praktik pendanaan kampanye sangat erat kaitannya dengan akuntabilitas lembaga-lembaga politik pasca pemilu. Kampanye dan pendanaan kampanye memuat pesan dan janji integritas aktor-aktor politik dengan penymbang dana sebelum menduduki posisi di lembaga politik akan membentuk pola kepada perbuatan-perbuatan yang menyimpang. Kecenderungannya adalah penyalahgunaan wewenang dan korupsi.

Integritas dan akuntabilitas aktor-aktor ini dalam menjalankan posisinya di ranah politik dan mengelola kekuasaan kerap masih bisa dikaitkan dengan pendanaan kampanye. Artinya, isu pendanaan kampanye menjadi salah satu sendi penting dalam membentuk tata kelola demokrasi yang bebas dari kolusi, korupsi, dan nepotisme (democratic governance). Aktor-aktor politik yang ketika Pemilu memiliki catatan pendanaan politik yang buruk pasti akan terancam posisi politiknya atau menjadi catatan skandal publik di kemudian hari. Oleh karena itu kelemahan-kelemahan pengaturan dana kampanye yang masih menjadi celah dan berpotensi melahirkan korupsi kebijakan pasca pemilu antara lain: Pertama, yaitu tidak adanya batasan dana kampanye dari sumbangan para calon sendiri. Di satu sisi, banyak sumbangan yang melebihi batasan sumbangan perorangan dan perusahaan akan dilewatkan melalui pintu sumbangan dari para calon pasangan sendiri. Persoalan kesenjangan dana kampanye yang dilaporkan dibawah tim kampanye dengan kerja elektoral yang dilakukan tim sukses secara informal menjadikan tingginya sumbangan yang bersifat mengikat untuk kepentingan politik uang.

Kedua, minim pengaturan mengenai batasan dalam komposisi penyumbang yang berasal dari korporasi swasta atau pengusaha, hal ini memungkinkan lahirnya kebijakan yang cenderung koruptif akibat pola quid pro quo donations. Ketiga, jenis audit yang digunakan adalah sekedar audit kepatuhan, padahal apabila kemudian diatur penggunaan metode pemeriksaan atau audit investigasi, maka akan memperjelas siapa pemodal di balik kandidat. Tanpa audit investigasi, maka akan terdapat upaya kandidat untuk dapat memanipulasi laporan sumber dana kampanyenya. Artinya, dana kampanye yang dilaporkan tidak mencerminkan kondisi sebenarnya.

Merujuk kepada rumusan masalah kedua, maka pengaturan dana kampanye pemilu yang dimuarakan kepada pola kebijakan penguatan moral dan system demokrasi yang bersih dari korupsi, kolusi, dan Nepotisme akan menjadi titik tolak yang strategis dalam upaya pemberantasan korupsi pasca pemilu di Indonesia, selain itu juga dapat menjadi satu alat ukur untuk menilai apakah aspek akuntabilitas pendanaan di dalam kampanye Pemilu sudah berjalan secara transparan dan akuntabel dalam kontestasi pemilu ke depan. Oleh karena itu perubahan-perubahan yang perlu dilakukan untuk mengoptimalisasi regulasi pembatasan dana kampanye adalah, pertama, pembatasan secara tegas dana kampanye yang berasal dari 
perseorangan yang kemudian memiliki rasio yang wajar dari laporan harta kekayaan pasangan calon.

Kedua, penegasan pengaturan komposisi atau rasio pemberi sumbangan dari dana kampanye yang dilaporkan. Disaat yang bersamaan harus ada perbaikan secara substantif dan sinkronisasi antara laporan dana kampanye dengan rekening khusus dana kampanye. Selama ini laporan dana kampanye dan rekening khusus dana kampanye tidak menggambarkan realitas arus penerimaan dan pengeluaran dana kampanye. Sehingga sistematisasi penggunaan dana kampanye dapat diterapkan yaitu dana kampanye yang digunakan adalah dana kampanye yang berada di rekening khusus. Ketiga, reformulasi sanksi pelanggaran pelaporan dana kampanye dengan pemberian kewajiban menyerahkan ke kas negara, sehingga apabila ada kelebihan dana dari pembatasan yang seharusnya ditaati, terdapat ancaman sanksi wajib menyerahkan kelebihan dana kampanye tersebut ke kas negara. Keempat, penggunaan metode pemeriksaan atau audit investigasi. Hal ini akan memperjelas siapa pemodal di balik kandidat. Tanpa audit investigasi, maka akan terdapat upaya kandidat untuk dapat memanipulasi laporan sumber dana kampanyenya. Artinya, dana kampanye yang dilaporkan tidak mencerminkan kondisi sebenarnya.

Berdasarkan kesimpulan sebagaimana diuraikan diatas, maka adanya pencapaian tujuan pengaturan dana kampanye untuk menunjukan bahwa pemilu adalah menciptakan persaingan yang sehat (fairness) dan terbebas dari praktek transaksitransaksi mencurigakan dapat dihindari dan merupakan prasyarat penting dalam membangun kualitas dan integritas proses pemilu yang diselenggarakan.

\section{DAFTAR PUSTAKA}

\section{A. Buku}

Ann Elliott, Kimberly, 1999, Korupsi dan Ekonomi Dunia, Yayasan Obor Indonesia, Jakarta.

Corrado, Anthony, et al., 1997, Campaign Finance Reform: A Sourcebook, Brookings Institution Press, Washington.

Casas, Kevin, et al., 2016, The Cost of Democracy: Essays on Political Finance in Latin America, Inter-American Dialogue, Washington.

Edwin, Keit, et al., 2006, Party Funding and Campaign Financing in International Perspective, Hart Publishing, Oregon.

Falguera, Elin, et al., 2014, Funding of Political Parties andElection Campaigns: A Handbook on Political Finance, International Institute for Democracy and Electoral Assistance, Stromsborg.

Herman, Alexander, et al., 1994, Comparative Political Finance among the Democracies, Westview Press, Boulder.

Hodess, Robin, 2004, Political Corruption, Transparency International Global
Corruption Report.

Irawan, Ade, et al., 2012, Korupsi Pemilukada, Indonesian Corruption Watch, Jakarta.

Irawan, Ade, et al., 2014, Panduan Pemantauan Korupsi Pemilu, Indonesia Corruption Watch, Jakarta.

Levush, Richard, 1995, Report for Congress: Campaign Financing of National Elections in Selected Foreign Countries, Library of Congress, Law Library, Washington D.C.

M. Afifuddin, et.al, 2015, Menguak Dana Kampanye Dalam Pemilu Legislatif 2014: Temuan Pemantauan di Tiga Provinsi Kalimantan Selatan, Lampung dan Maluku, Jaringan Pendidikan Pemilih untuk Rakyat, Jakarta.

Open Society Institute, 2005, Monitoring Election Campaign Finance: a Handbook For NGOs, Open Society Institute.

Philp, Mark, 1997, Defining Political Corruption, Political Studies Association, Blackwell Publishers. 
Pinto-Duschinsky, et al., 1999, Campaign Finance In Foreign Countries: Legal Regulation And Political Practices, International Foundation for Election Systems, Washington.

Pinto-Duschinsky,Michael, et.al, 2003, Money and Politics Handbook: Office of Democracy and Governance, USAID.

Silke Pfeiffer, 2004, Vote Buying and Its Implication for Democracy: evidence from Latin America, TI Global Report.

Supriyanto, Didik, et al., 2013, Basa-Basi Dana Kampanye Pengabaian Prinsip Transparansi Dan Akuntabilitas Peserta Pemilu, Perludem, Jakarta.

Supriyanto, Didik, et al, 2015, Dana Kampanye Pilkada: Pengaturan Teknis Tentang Sumbangan, Pengeluaran, dan Pelaporan Berdasarkan UU No 1/2015 Juncto UU No 8/2015, Perludem, Jakarta.

Terracino, Julio Bacio dan Hamada, Yukihiko, 2014, Financing Democracy: Supporting Better Public Policies and Preventing Policy Capture, OECD Washington.

Vit Šimral, The Funding and Oversight of Political Parties and Election Campaigns in East Central Europe, (Prague: Open Society Foundations) .

Ware, Alan, 1995, Political Party and Party Systems, Oxford University Press, London.

\section{B. Artikel Jurnal}

Acemoglu, Daron, "Politics and Economics in Weak and Strong States", Journal of Monetary Economics Vol. 52, 2005.

Brown, Rebecca L. dan Martin Andrew D. "Rhetoric and Reality: Testing the Harm of Campaign Spending." New York University Law Review, Vol. 90, 2015.

Coate, Stephen, "Pareto-Improving Campaign Finance Policy". American Economic Review, Vol. 94, No. 3, 2004.

Fukuoka, Yuki, "Politics, Business and the State in Post-Soeharto Indonesia." Contemporary Southeast Asia Vol. 34, No. 1, 2012.
Ikstens, Jānis, Pinto-Duschinsky, Michael, Smilov, Daniel, Walecki, Marcin, "Political Finance in Central Eastern Europe: An Interim Report", Österreichische Zeitschrift für Politikwissenschaft, Vol. 31, No. 1, 2002.

Issacharof, Samuel, "The Constitutional Logic of Campaign Finance Regulation", Pepperdine Law Review Vol. 36, No. 2, 2009.

Prat, Andrea, "Campaign Advertising and Voter Welfare", Review of Economic Studies, Vol. 69, No. 4, 2002.

Scarrow, Susan E., "Political Finance in Comparative Perspective". Annual Review of Political Science, Vol. 10, No. 1, 2007.

\section{Hasil Penelitian/Tugas Akhir}

Bruno, Speck. 2013, Money in politics: Sound political competition and trust in government. Technical report, Background paper, Washington.

Burhanuddin, Muhtadi, 2018, Buying Votes in Indonesia: Partisans, Personal Networks, And Winning Margins, Disertasi, Australia National University, Canbera.

Emmy, Hafild, 2008, Laporan Studi Standar Akuntasi Keuangan Khusus Partai Politik, Transparency International dan Indonesia Transparency International, Jakarta.

Fitriyah, 2018, Botoh dalam Pilkada: Studi Kasus Dua Daerah di Jawa Tengah, Disertasi, Program Doktor Ilmu Sosial-FISIP Universitas Diponegoro, Semarang.

Hayati, Tri, 2011, Perizinan Pertambangan Di Era Reformasi Pemerintahan Daerah: Studi Tentang Perizinan Pertambangan Timah Di Pulau Bangka, Disertasi, Fakultas Hukum Universitas Indonesia, Jakarta.

KPK, 2016, Laporan Studi Potensi Benturan Kepentingan Dalam Pendanaan Pilkada. Direktorat penelitian dan Pengembangan KPK, Jakarta.

Varjão, Eric, 2017, Money and Politics: The Effects of Campaign Spending Limits on Political Competition and Incumbency Advantage, 
National Bureau Of Economic Research, Cambirdge.

\section{Makalah/Pidato}

Fowler, Anthony, et al., 2017, "Quid Pro Quo? Corporate Returns To Campaign Contributions." Makalah, tanpa forum.

Walecki, Marcin, 2007, "Spending limits as a policy option", IFES Political Finance White Paper Series.

\section{E. Artikel dalam Antologi dengan Editor}

Mietzner, Marcus, "Funding Pilkada: Illegal Campaign Financing in Indonesia's Local Elections", dalam Aspinall, Edward dan van Klinken, Gerry, 2011, The State and Illegality In Indonesia, KITLV Press, Leiden.

Nye, JS., "Political Corruption: A cost-benefit analysis" dalam Heidenheimer, A.J., Johnston, M., LeVine, V, 1989, Political Corruption; A Hand Book, New Brunswick, New Jersey.

Sukmajati, Mada, et al., "Pendahuluan: Pembiayaan Pemilu di Indonesia", dalam Mada Sukmajati dan Aditya Perdana, 2018, Pembiayaan Pemilu di Indonesia, Bawaslu, Jakarta.

\section{F. Artikel Majalah atau Koran}

Ambaranie, Movanita, "Abai Soal Dana Kampanye, Calon Kepala Daerah Bisa Digugurkan" Kompas, 17 Maret 2018.

Alsadad, Rudi, "Sandiaga Habiskan Rp 108 Miliar Selama Pilkada DKI", Kompas, 18 Maret 2017.

Fahmi, Khairul, "Pembatasan Dana Kampanye Pilkada", Media Indonesia, 10 Maret 2015.

Waldman, Paul, "How Our Campaign Finance System Compares to Other Countries", The American Prospect, 4 April 2014.

\section{G. Internet}

Kompas, Team, "Biaya Pilkada Picu Korupsi”, http:// www.ti.or.id/index.php/ news/2016/09/28/ biaya-pilkada-picu-korupsi, diakses tanggal
20 Desember 2019.

Felix, Natnaniel, "Bisnis Tambang Merebak Seiring Pilkada Serentak", https://tirto.id/bisnistambang-merebak-seiring-pilkada-serentakcG4x, diakses pada 20 Desember 2019.

\section{H. Peraturan Perundang-undangan}

Undang-Undang Nomor 3 Tahun 1999 tentang Pemilihan Umum (Lembaran Negara Republik Indonesia Tahun 1999 Nomor 23, Tambahan Lembaran Negara Republik Indonesia Nomor 3810).

Undang-Undang Nomor 12 Tahun 2003 tentang Pemilihan Umum Anggota Dewan Perwakilan Rakyat, Dewan Perwakilan Daerah, Dan Dewan Perwakilan Rakyat Daerah (Lembaran Negara Republik Indonesia Tahun 2003 Nomor 37, Tambahan Lembaran Negara Republik Indonesia Nomor 4277).

Undang-Undang Nomor 10 Tahun 2008 tentang tentang Pemilihan Umum Anggota Dewan Perwakilan Rakyat, Dewan Perwakilan Daerah, dan Dewan Perwakilan Rakyat Daerah (Lembaran Negara Republik Indonesia Tahun 2008 Nomor 51, Tambahan Lembaran Negara Republik Indonesia Nomor 4836).

Undang-Undang Nomor 8 Tahun 2012 tentang Pemilihan Umum Anggota Dewan Perwakilan Rakyat, Dewan Perwakilan Daerah, Dan Dewan Perwakilan Rakyat Daerah (Lembaran Negara Republik Indonesia Tahun 2012 Nomor 117, Tambahan Lembaran Negara Republik Indonesia Nomor 5316).

Undang-Undang Nomor 32 Tahun 2004 tentang Pemerintahan Daerah (Lembaran Negara Republik Indonesia Tahun 2004 Nomor 125, Tambahan Lembaran Negara Republik Indonesia Nomor 4437).

Peraturan Pemerintah Pengganti Undang-Undang Nomor 1 Tahun 2014 Tentang Pemilihan Gubernur, Bupati, Dan Walikota (Lembaran 
Negara Republik Indonesia Tahun 2014

Nomor 245, Tambahan Lembaran Negara

Republik Indonesia Nomor 5588).

Undang-Undang Nomor 1 Tahun 2015 tentang

Penetapan Peraturan Pemerintah Penggant Undang-Undang Nomor 1 Tahun 2014 Tentang Pemilihan Gubernur, Bupati, Dan Walikota Menjadi Undang-Undang (Lembaran Negara Republik Indonesia Tahun 2015 Nomor 23, Tambahan Lembaran Negara Republik Indonesia Nomor 5656).

Undang-Undang Nomor 8 Tahun 2015 tentang Perubahan Atas Undang-Undang Nomor 1 Tahun 2015 Tentang Penetapan Peraturan Pemerintah Pengganti Undang-Undang Nomor 1 Tahun 2014 Tentang Pemilihan Gubernur, Bupati, Dan Walikota Menjadi Undang-Undang (Lembaran Negara Republik Indonesia Tahun 2015 Nomor 57, Tambahan Lembaran Negara Republik Indonesia Nomor 5678).

Undang-Undang Nomor 10 Tahun 2016 tentang Perubahan Kedua Atas Undang-Undang Nomor 1 Tahun 2015 Tentang Penetapan Peraturan Pemerintah Pengganti UndangUndang Nomor 1 Tahun 2014 Tentang Pemilihan Gubernur, Bupati, Dan Walikota Menjadi Undang-Undang (Lembaran Negara
Republik Indonesia Tahun 2016 Nomor 130, Tambahan Lembaran Negara Republik Indonesia Nomor 5898).

Peraturan Komisi Pemilihan Umum No 8 Tahun 2015 Tentang Dana Kampanye Peserta Pemilihan Gubernur dan Wakil Gubernur, Bupati dan Wakil Bupati, dan/atau, Walikota dan Wakil Walikota. (Berita Negara Republik Indonesia Tahun 2015 Nomor 719).

Peraturan KPU No 13 Tahun 2016 tentang Perubahan atas Peraturan Komisi Pemilihan Umum No 8 Tahun 2015 Tentang Dana Kampanye Peserta Pemilihan Gubernur dan Wakil Gubernur, Bupati dan Wakil Bupati, dan/atau, Walikota dan Wakil Walikota. (Berita Negara Republik Indonesia Tahun 2016 Nomor 1389).

Peraturan Komisi Pemilihan Umum No 5 Tahun 2017 Tentang Dana Kampanye Peserta Pemilihan Gubernur dan Wakil Gubernur, Bupati dan Wakil Bupati, dan/atau, Walikota dan Wakil Walikota. (Berita Negara Republik Indonesia Tahun 2017 Nomor 828).

\section{Putusan Pengadilan}

Putusan Pengadilan Tinggi DKI Jakarta Nomor 16/ Pid.Sus-TPK/2018/PT.DKI perihal Banding perkara Nur Alam, 28 Maret 2018. 